\title{
Are Small Firm Employment Responses Different from Large Firms in Times of Recession?
}

\begin{abstract}
This paper uses British large scale survey data to examine the extent to which the recent financial crisis has affected firms' operational activity, and whether or not the existence of human resource (HR) practices have influenced firms' response to recession and workers' job experience. Our findings suggest that SMEs are more vulnerable during times of economic hardship than larger firms, but those with HR practices have shown more resilience to the downturn. Also, we find that having HR practices increases the likelihood of the firm to adopt organisational measures although the response to recession differs significantly between smaller and larger firms. Finally the results indicate differences in workers' job experience during the recession which is moderated by high and low levels of management formality.
\end{abstract}




\section{Introduction}

The recent financial crisis, triggered by the collapse of the US subprime mortgage market, has led to significant losses in financial institutions and produced major liquidity problems for banks and in turn for firms and entrepreneurs (Peston, 2008; Cable, 2009). It is argued that a recession originating from financial disruption is generally severe and persistent (IMF, 2009) given the adverse impact on the supply of finance to firms, investors and consumers (Kitching et al., 2009a). As a result, industrial output and market demand fell sharply, resulting in a significant increase in unemployment, corporate bankruptcies and redundancies (Gennard, 2009). Britain is an economy with a strong degree of dependence on financial services and a high level of household indebtedness (Weale, 2009; Simpson, 2009), and as expected, was hit severely by the financial downturn with significant drops in capital spending, investment and innovation. Many large high profile firms were affected by the recession, including the retailers Woolworths and Borders Books which both ceased trading, as well as automotive manufacturers such as Jaguar Land Rover and Honda which laid off workers and introduced short-time working in response to a major slump in sales (Guardian, 2010). Yet 99\% of British enterprises are SMEs, and the evidence suggests many sectors which have a high proportion of SMEs -such as construction, business services and manufacturing -were particularly vulnerable to recession (Price et al., 2013). Has the recession affected small and large firms differently? Do the responses of small and large firms differ in times of recession in terms of HRM practices? How do employees in small and large firms experience the effects of this economic shock? These are the three overarching questions guiding our research.

The existing literature suggests that external uncertainty and economic shocks can impact small and large firms differently (Smallbone et al., 2012; Latham, 2009). In fact small organisations differ in nature from large organisations (Liff and Turner, 1999), given the distinctive factors that characterise enterprises of different size. Specifically, as a result of their relative resource poverty, weak external environment control, limited options of financing (Smallbone et al., 2012; Westhead and Storey, 1996) and access to financial resources derived from imperfections in capital market allocation (Revest and Sapio, 2010; 
Cressy, 2002; Auerswald and Branscomb, 2003), a priori, smaller firms are expected to be less resilient to a recessionary environment than larger firms (Field and Franklin, 2013; Sheehan, 2013). McCann (2008) reports that $62 \%$ of UK small firms experienced negative effects of the 'credit crunch'; half of these have been affected directly by more expensive finance and the rest indirectly by poor sales performance.

Given this challenging external context, a key business issue, for both small and large firms, is the management of people. A central debate in HRM is the extent to which people are like other resources to be utilised and dispensed with when appropriate, or a distinctive type of resource requiring investment, development and nurturing. The latter view informs much of extensive literature on strategic HRM (SHRM) concerned with understanding the link between people management activities and organisational performance (for example Sheehan, 2013). Yet while the SHRM literature is dominated by studies of large firms, entrepreneurship scholars have increasingly appealed for more research at the intersection of HRM and entrepreneurship (e.g. Baron, 2003; Katz et al., 2000). After all, many entrepreneurs must recruit, allocate work to, motivate and retain employees who will help their business to grow and survive (Leung, 2004; Heneman et al., 2000; Katz et al., 2000). However, a recurring theme in the literature is that in smaller firms many activities associated with the management of work and people, are undertaken more informally and often without the support of a specialist HR department or even an HR manager (Saridakis et.al, 2013). Nevertheless, all employers, large and small, must manage HR issues irrespective of whether they use HR terminology to describe such activities, or whether the mechanisms used are formal or informal. For smaller and entrepreneurial firms, effective HRM policies and practices may help firms to enhance their performance in key areas such as creativity, innovation, quality, flexibility and entrepreneurial behaviour (see for example Dabić et al., 2011; Hayton et al., 2013). More pragmatically, HRM might also be concerned with mitigating the risks of mismanagement which could hinder organisational survival (Barrett and Mayson, 2006), an issue which becomes even more acute in times of economic uncertainty (e.g. Brundage and Koziel, 2010; Bidya, 2009; Mohrman and Worley, 2009). In short, while HR might be viewed as a bureaucratic and corporate phenomenon, HRM contributes significantly to the success or failure of high-growth entrepreneurial firms (Tanksy and Heneman, 2006). 
In tough economic conditions, firms tend to respond by introducing a wide range of cost reduction measures, and often this includes expenditure in key areas of HRM such as staffing levels and pay and rewards. In this context, firm size is recognised as influential as it can both enable and constrain strategic choices regarding people management and employment relations (Kitching and Marlow, 2013). On the one hand, small firms are relatively labour-intensive and less likely to be unionised, providing greater opportunities to make labour-related cost-savings during recession. On the other hand, small firms tend to operate with less organisational 'slack' and require minimum numbers to be able to operate effectively thus inhibiting opportunities to reduce their workforce (Kitching et al., 2009). Some commentators (e.g. Wickramasinghe and Perera, 2012; Latham, 2009; Shama, 1993) suggest that a firm-size effect may be extended to a firm's employment related responses when facing such external environmental uncertainty. Latham (2009), for example, reports that cost and headcount reductions occurred mainly in large firms during the 2001/3 economic recession, a finding that is reflected in a study of small firms that found evidence of their resilience rather than weakness (Smallbone et al., 2012). Hence, although there has been a growing body of knowledge examining the relationship between firm size and strategic responses during adverse macro-economic conditions, this issue remains relatively unexplored. Previous analyses have also relied on evidence collected from owners and managers with little or no attention paid to the experiences of employees. The purpose of our paper is to begin to address this gap. We use a matched employer-employee dataset from the latest wave of the Workplace Employment Relations Study (WERS2011) to investigate the impact of the recent recession on British firms by firm size, the effects of the strategic responses of managers in SMEs on employment, and employees' experience of working in a relatively volatile economic environment.

Importantly, our analysis enables us to empirically examine whether the HRM policies described and adopted by managers are shared with employees' views and experiences (Wright and Boswell, 2002). As Guest (1999) suggests, the impact of HRM should be considered with regard to both the outcomes relevant to workers as well as businesses, both as a point of principle as well as to fully inform HRM debates. Our approach allows us to compare the organisation's intended people management strategies, as reported by managers, with those activities as experienced by employees. This is important as employee perceptions, attitudes and behaviours are generally considered to be key to understanding the HR 'causal chain’ (Purcell et al., 2009), yet there has been a neglect of employees in the analysis of HRM 
and performance. Indeed a review of 104 studies of HRM and performance by Boselie et al. (2005), reveals only 11 used employee survey data. This might not be a problem if we can assume that management views and employee views are normally the same, and that 'what is good for organisation is good for the worker'. However, such unitarist perspectives belie the pluralist traditions of much HR scholarship in the UK and Europe which recognise that differences and disagreements often emerge (Guest, 2002). In other words, there may be a disconnection between what managers believe is practised, and what employees observe or perceive in the organisation (Van Den Berg et al., 1999: 302). These issues are particularly salient when organisations are seeking to make potentially difficult and contentious decisions regarding reducing costs and retrenchment in times of recession.

Hence, the objectives of this paper are fourfold. First, we examine the impact of recent recession on small and large firms. Second, we study potential differences in actions taken by those firms in response to economic adversity. Third, we examine to what extent the actions adopted by managers/owners are consistent with work changes experienced by the employees. Finally, we investigate the role of HR practices on managers' employment responses and employees' experience of work during recession. The rest of the article is organised as follows. Section two provides additional theoretical context, and also suggests the characteristics that differentiate small and large firms, especially in relation to employment management practices. Drawing on this, we then present our hypotheses. Section three describes the data sources, measures of key variables and research methods. Section four presents and discusses the empirical findings. The final section presents the conclusions and discusses the implications and suggests directions for future research.

\section{Literature review and hypothesis development}

\subsection{Managing in recession in small and large firms}

A recurring question in the literature is the extent to which small businesses can simply be viewed as 'little big businesses', or whether issues such as resource poverty distinguish small firms from large firms (Welsh and White, 1981), and thus small firms encounter particular challenges and require distinctive management approaches. Specifically, small firms are constrained by limited accessibility to financial resources, time, and a lack of the managerial resources and expertise (Kotey and Sheridan, 2001; Chandler and McEvoy, 2000). Small 
firms are also less likely than large firms to achieve product and service diversification derived from economics scale or/and scope (Ghemawat, 1986; Porter, 1980). Consequently, Ryans (1989) suggested that the management of a small firm involves a different set of experiences, risks and needs to the management of a large firm. For example, discretion over firm strategies and management policy are severely constrained by the availability of financial and human capital resources, as well as other entrepreneurial circumstances (Smallbone et al., 2012; Cassell et al., 2002) compared with the resources generally available to, and exploited by, larger firms (Kroon et al., 2012). A superior resource base and greater market power suggests that large business enterprises possess greater discretion and more options than SMEs over strategic choices and responses during recession (Singh and Vohra, 2009; Smallbone et al., 2012).

Access to finance is particularly important. Although small firms’ owners have a preference for internal finance (Myers, 1984; Myers and Majluf, 1984), bank lending still remains their largest source of external finance, mainly due to a lack of alternative financing options (e.g. working capital, stock financing) (OECD, 2009). Given asymmetric information and imperfect markets (Hillier and Inbrahimo, 1993; Binks et al., 1992), lending institutions require higher risk premiums to compensate higher uncertainty and risk associated with investing in small firms (Cowling et al., 2012). This makes external finance significantly more difficult and expensive for small firms to obtain. Cowling et al. (2012) argue that firm size appears to be the primary lending criterion used by financial institutions during an economic crisis, whereas a richer set of factors are taken into consideration for the periods of economic stability and growth. This suggests that small businesses are particularly constrained in terms of their strategic responses to environmental threats during recessions. In contrast, lower interest rates and a wider range of financing options (e.g. equity, company share), mean it is easier for large firms to obtain the financial resources that allow them to choose more capital-intensive methods, a higher capital-labour ratio, and higher utilisation rates via multiple shifts and new equipment (Idson and Oi, 1999).

A further strand of literature has examined the differences in the management of people between small and large firms. Several studies have been concerned with the employee experience of work in small firms, and this is to be welcomed given the paucity of employee views in much of the data on HR in large firms. However, this debate has been divided between two camps: the 'small is beautiful' and the 'small is brutal' perspectives. While 
'beautiful' firms are portrayed as benefiting from a good working environment and positive working relationships, 'brutal' firms are associated with low pay, few career opportunities and strict management regimes. However, rather than explaining how people are managed in smaller firms, both positions effectively illustrate the two extremes of HR, with hard HRM at one end and soft HRM at the other. In part this might be because they over-emphasise the importance of size, and underplay the potential impact of other variables such as personal preferences, customer and supplier relationships, labour market power, and institutional context (Edwards and Ram, 2006), which may all shape management choices.

A common theme, however, is that people management practices are generally more informal in smaller organisations. Informal workplace relations have been defined as "a process of workforce engagement, collective and/or individual, based mainly on unwritten customs and tacit understandings that arise out of the interactions of the parties at work" (Ram et al., 2001: 846), and that the close working proximity and mutual dependence of employer and employees encourages informal accommodation and flexibility. Again, this rejects a unitarist view of workplace relations, and suggests the need for some regulation of employment, and the accommodation of sometimes competing stakeholder interests to achieve a 'negotiated order' (Ram, 1994). Informality may be the result of management preference or experiences of what has worked in the past, indifference or even a dislike of more formal HRM, believed to be at odds with entrepreneurial firms. Of course small firms, generally, have a much flatter, more flexible and simpler organisational structure. The direct control by the owner-managers reduces the need for the detailed documentation and accountability resulting from delegation (Kotey and Slade, 2005), and offers greater flexibility in adapting to change (Mintzberg et al., 1995). More generally, given their comparatively small workforce size, scope of operation and their access to fewer financial resources, SMEs use a less structured organisational approach, often working without highly formalised business strategies (Scott et al., 1989) or human resource structures and procedures.

Of course, informality is a matter of degree (Edwards and Ram, 2009) and may, for example, depend upon the particular issue concerned. Formality is also unlikely to be static, and may evolve over time. As entrepreneurial businesses grow (in terms of workforce size or age) their employment practices eventually become more formalised (see, for example, Storey et al., 2010; Kotey and Slade, 2005; Aldrich and Langton, 1997 amongst others). For example, it is impractical for senior decision makers to communicate directly with all levels of workers 
(Storey et al., 2010), meaning more formalised and bureaucratic procedures are adopted to standardise the process and convey consistent information to the workforce. As the workforce size increases, the organisational structure becomes more complex and hierarchical, and standardised and formalised working procedures are required for consistent and efficient application and fair treatment of each employee (Child, 1972). Documented procedures are introduced to ensure accountability since owners-managers lose direct control of low-level operations as the firm grows (Kotey and Slade, 2005). In short, management strategy in different sized firms can be thought of as the result of the interplay of internal structure (e.g. firm size, organisational structure) and external environment (e.g. product market, market demand) (Edwards et al., 2006; Bacon and Hoque, 2005).

As a result of the differences discussed above, smaller and larger firms may be expected to respond differently to episodes of uncertainty. The nature of external environmental threats, and the mechanisms through which they are transmitted and tackled, differ between small and large organisations (Curran, 1996). While large firms face an internal uncertainty as a result of a large and diverse workforce ((Nguyen and Bryant, 2004), small firms have more control over their internal environment because of the closer proximity between employers, managers and workers. However, they are also particularly susceptible to changes in costs, external shocks and powerful external actors (Storey and Skyes, 1996). The Marxist-influenced 'dependency theory' (Rainnie, 1989) suggests that, in their marginal position as market price takers, small employers lack the power to influence prices and tend to depend on a single, or limited, number of customers. This uncertainty and fragility might be reflected in the management practices and style of owner-managers, meaning small might not be 'beautiful' (Rainnie, 1989). Storey et al. (2010) suggests that small business owners and managers react to environmental uncertainty by taking actions that emphasise short-term terms and conditions of employment that can be adjusted at low cost in the case of changed circumstances. Hill and Stewart (2000) argue that an informal approach is more suited to small firms because flexibility and informality help them to cope with environmental uncertainty, while Marlow and Patton (1993) suggest that SMEs are flexible and able to adapt to a changing environment and respond more swiftly and effectively (also see Kitching et al., 2009a).

More specifically, in times of recession, Smallbone et al. (2012) identify two broad views with respect to how firms of different size are affected: the "vulnerability" and 
"resilience" views. In the vulnerability view, smaller firms are perceived to be more vulnerable and susceptible to external shocks whereas their larger counterparts are believed to be more resilient. The argument is largely linked to a number of the size-related factors that characterise small firms we highlighted earlier, such as limited financial resources, narrow customer base and product lines across which to spread risk and less bargaining power with a variety of external actors, e.g. customers, suppliers and finance providers (Smallbone et al., 2012; Cowling et al., 2012). These factors significantly determine a firm's capability to survive and endure difficult market conditions, and to avoid performance decline. In particular, given the onset of a credit crunch, as well as the reduction of bank lending and risk policies, small firms are expected to experience a tightening of the credit market that can influence their capabilities to respond to recession considerably (Smallbone et al., 2012). Most of the existing work has shown that SMEs are more prone to cease trading than their large counterparts and their performance is significantly more volatile in the short-, mediumand long-term (Storey, 1994; 2011). Sahin et al. (2011) investigate the factors that caused small US businesses to be hit harder than large firms during the latest recession, and find that economic uncertainty, poor sales stemming from reduced consumer demand, and limited credit availability are all explanations of the relatively weak performance and sluggish recovery of small firms.

Conversely, the resilience view stresses that the flexibility and adaptability of small firms may enable them to survive, or possibly even thrive, during periods of economic recession. This flexibility is evident in terms of adjusting resource inputs, processes, prices and outputs (Reid, 2007; Bednarzik, 2000). Small firms' owners, when faced with environmental volatility and economic restructures and changes, will rely on flexible organisational routines and closeness to the market to find niches that may offer a moderate level of revenue generations (Cowling et al., 2014; Latham, 2009). Surveys of UK small firms have shown that small firms exhibit a strong level of resilience, flexibility, adaptability and absorptive capacity in recessions (see for example Price et al., 2013; Anderson and Russell, 2009). However, the majority of studies tend to suggest that small businesses are likely to perform less well and to be more vulnerable than larger firms during recession conditions, eventually affecting their growth and survival prospects (e.g. Field and Franklin, 2013; Chow and Dunkelberg, 2011; Fotopoulos and Louri, 2000). Superior resources (e.g. financial capital, human capital, network, market power) offer large firms a stronger position, greater scope for 
strategic choices and ultimately greater resilience to withstand difficult times (Kitching et al., 2009b). Given this disagreement in the current literature, we hypothesise that:

H1: Small firms are more likely than large firms to be adversely affected by, and are more vulnerable to, economic crisis.

\subsection{Small and large firms’ responses to managing human resources in recession}

In the face of a deep and prolonged downturn, firms are encouraged to adopt practices and devise strategies that build and strengthen capacity in the organisation, not only to survive in tough market conditions, but also to thrive in the future (Mohraman and Worley, 2009; Stefaniak et al., 2012). One particular management function that has experienced the farreaching effect of the economic downturn and fundamental change is managing human resources (Acas, 2009; CIPD 2009). Yet our understanding of how firms manage HR in recession remains embryonic, and even less is known about the employment related response to economic recession across firms of different sizes (Latham, 2009). Only a limited number of studies have investigated the HRM practices adopted by small and large firms during recession. For example, using two random samples of non-managerial employees and senior employees in software development firms in Sri Lanka, Wickramasinghe and Perera (2012) find that cost reduction strategies significantly vary by firm size. In particular, reductions in training and development opportunities for employees, and reductions in financial rewards and benefits are more likely to occur in SMEs than in large firms.

Many commentators have suggested that SMEs are distinctive from large organisations in terms of both their general management and HR approaches, and in terms of the latter, smaller firms tend to be more informal and flexible (Marlow, 2005; Kotey and Slade, 2005; Storey, 2002). In times of recession, informal HR may be double-edged. On the one hand, the prevalence of informal HRM activities in SMEs could prove advantageous when there is a need to be flexible and to respond quickly to market conditions and environmental uncertainty (Hill and Stewart, 2000), compared with larger, more bureaucratic organisations. Conversely, the lack of formalised strategies and practices can also lead to poor HR outcomes, skill shortages and gaps (Small Business Service, 2001) as well as lower levels of compliance with legislation. SMEs are the principal source of unfair dismissal applications to UK employment tribunals (Earnshaw et al., 2000; Saridakis et al., 2008). 
One of the most contested HR issues concerns staffing levels. In practice, this might mean reducing the size of the labour force through a mix of layoffs, freezing recruitment, and natural wastage. Rones (1981) argues that the ability and willingness of the firm to use -and of employees to accept -layoffs are in the determination of redundancy related benefit. In this case, we expect to observe a firm-size effect on layoffs. First, employees in large British firms are more likely to secure an enhanced redundancy compensation package that exceeds the statutory minimum and as such large firms might expect more success in attracting volunteers. The non-taxable status of redundancy pay (up to $£ 30,000$ in the UK) may also act as an incentive to layoffs, given that the real value of benefit pay is relatively greater than taxable earned income (Rones, 1981). Second, trade unions have played a critical role in protecting employees' interests and statutory rights through negotiated responses and collective bargaining agreements (Acas, 2009), and again this may make voluntary terms more palatable to employees of large firms. As there is a considerably lower presence of trade unions in small firms (see Wright, 2011; Forth et al., 2006), we might expect fewer such agreements amongst such firms. Thirdly, the recession has particularly impacted on export-oriented British businesses because of the UK's close proximity to the troubled Eurozone export markets, and although large firms make up only $0.12 \%$ of all business and employ fewer employees than SMEs in the UK, they account for approximately 53\% of UK registered firms engaged in international trade compared to $11.8 \%$ of small firms, and $41.8 \%$ of medium firms (Ward and Rhodes, 2014). Fourthly, there is a sector dimension to any recession, compounding any simple size-effect. Gennard (2009) found that the UK sectors hit hardest, in terms of job loss and recruitment shrinkages were those often associated with larger organisations including banking, automobiles, information and communication technology, chemical and pharmaceuticals, and retail. Finally, because of their larger workforce and more complex internal labour markets, large organisations may identify more scope to make workforce reductions. On the other hand, since small firms are characterised as resource constrained, labour-intensive and operating in the service industry, they may have a greater incentive to retain their workforce and avoid extra recruitment costs by adopting alternative retrenchment strategies, as well as less 'slack' to cut. Personal relationships with employees may also mean that owner/managers are more reluctant to implement such measures.

Of course the arguments presented above are far from clear cut. Large firms may be reluctant to make layoffs which may reduce the firm's capacity to exploit opportunities in the upturn as it takes time and more money to acquire and mobilise resources (Brundage and 
Koziel 2010; Rao, 2009). They may also be concerned about the loss of knowledge and skills which may be difficult to replace, as well as the potential for reputational damage or industrial relations conflict. On the other hand, as Marlow (2002) notes, small business workers also have a low level of awareness of legal entitlement and are not keen to exercise their rights because of employment insecurity, and this may put employees in SMEs in a more precarious position during periods of economic uncertainty and disruption. Nevertheless, on balance we hypothesise that:

H2: Large firms are more likely than small firms to a) lay off their workforce and b) reduce new hires.

Layoffs, while hotly debated, are not necessarily the first response to falling product demand and a general slowdown in the economy; traditionally firms opt for alternative employment-related adjustments, such as cutting employees' working hours before shedding jobs (Roche et al., 2011; Rones, 1981). The primary advantages of flexible working arrangements are to avoid the immediate and short-run turnover costs of layoffs, as well as the longer term costs associated with recruiting, selecting and training new employees (Rones, 1981). Smaller firms typically have a higher incidence of flexible and informal working arrangements, given that such firms have lower levels of formal planning compared to large firms (Marlow et al., 2005). Indeed, it has been argued that small firms are not hindered by formal routines that must be adhered to when formulating strategic responses to an environmental threat (Ebben and Johnson, 2005; Forbes and Milliken, 1999). Rather, they leverage a more flexible organisational structure and processes when reacting to environmental changes and shocks (Carr et al., 2004; Kitching et al., 2009b). Broughton (2011) suggests that the economic crisis seems to have had the impact of increasing flexible practices and short time working arrangements in small business enterprises. Athey (2009) finds that flexible working practices have been particularly evident in the construction and manufacturing sectors, with many small employers asking workers to reduce working hours or take unpaid leave to survive a period of declining sales, rather than making redundancies. Informality and more personal relationships may also help in re-negotiating working hours with employees compared to negotiation through more formal employment relations institutions associated with larger firms. Hence, it is hypothesised that:

H3: Small firms are more likely than large firms to reduce employees’ working hours. 
Pay freezes or cuts are considered as another cheaper and effective alternative to laying off workers, avoiding losing valuable skills and saving costs for re-recruitment during recovery. Blundell et al. (2013) suggest three potential explanations for pay cuts during the recent recession, including imbalanced labour supply and demand ( $c f$ labour supply curve has shifted to the right), a reduction in the average quality of labour and the change in the composition of workforce ( $c f$ that shift towards more productive workers). Generally, firms that have experienced instability in sales and profitability are more likely to pass along some of this turbulence to their employees that reflected in increased volatility in earnings (Comin et al., 2008). We have argued earlier that a substantial decline in aggregate demand may impact more significantly on export-oriented large organisations, and therefore their employees' performance-related pay and income are more likely to be negatively affected. Comin et al. (2008) find that the effect of firm volatility on wage volatility in the US is driven by large firms. However, empirical evidence has also shown that pay cuts are not unproblematic. Many firms are resistant to pay cuts and employees' wages may maintain downward rigidity even during the tough periods of economic recessions (e.g. Yokoyama, 2004; Bewley, 1999). The dominant explanation is mainly situated in the analysis within the theory of wage rigidity developed by Solow (1979) and Akerlof (1982) that emphasises morale. Bewley (1999) found that pay cuts were not preferred to layoffs by many firms and used only in circumstances where the firm experienced serious problems during the recession of the early 1990's, due to the belief that nominal wage cuts damage morale across the entire workforce compared to the impact of more selective job cuts.

Acas (2009) suggests that trade unions play a central role in negotiating pay freezes or cuts during the recession, but the negotiation of terms and conditions with trade unions is very much a large firm and public sector phenomenon in Britain. The impact of union negotiations is also hard to predict: on the one hand there may be mutual understanding and agreement, while on the other trade unions may feel obliged to continue to deliver 'good' pay deals for their membership. In smaller firms, however, pay is more likely to be set unilaterally by management and pay rises more ad hoc and unpredictable. Yet small firms also face tighter financing options and lending criteria, and are more likely to experience liquidity and insolvency issues than their large counterparts (Cowling et al., 2012; European Commission, 2009). A cost saving scheme for constrained smaller firms to maintain survival rather than close down is to reserve cash and alleviating financing constraint by introducing pay cuts or freeze pay. Finally, employees in smaller firms tend to have a more personal relationship with 
the manager/owner as well as with colleagues, and closer participation in - or at least awareness of - organisational decision making (see, for example, Artz, 2008). It is conceivable that employees in smaller firms are perhaps more amenable to pay cuts or freezes during recession for the benefit of the business because they understand the rationale for such decisions. Alternatively, they may feel that they simply have little means of challenging such a policy. Therefore, we hypothesise that:

H4: Small firms are more likely than large firms to cut or freeze pay.

Employee training and development during recession could serve as an important retention and reward mechanism to retain key talent (Mohramn and Worley, 2009), especially when pay costs may be under pressure. However, many firms choose to reduce budget allocations for training during a financial crisis on the grounds that it is expensive and not always essential in the short-term. However, formal training is generally more likely to take place in large firms than small firms (Gibb, 1997), mainly because larger firms are in a stronger position in terms of achieving economies of scale and having relatively sufficient financial capital and managerial expertise. In contrast, SMEs rarely carry out formal trainingneeds analysis and operate a less systematic approach to employee training and development (Storey, 2004); indeed formal training may be viewed by owner-managers as an unaffordable luxury requiring both a financial outlay as well as the cost of unproductive labour. Employees in small firms are often expected to be multi-skilled in order to handle the fluid and more flexible nature of jobs, whereas formalised training and development might be aimed towards more specialised staff (MacMahon and Murphy, 1999), or more general management development courses, but flatter organisations also mean fewer formal management opportunities in SMEs. Rather, informal training approaches, such as on-the-job training are the predominant method and mainly directed to the solution of immediate work-related problems (Curran et al., 1996; Hill and Stewart, 2000). Alternatively, owner-managers may take direct responsibility for employee training and teach their preferred methods of doing things, especially in very small firms (Curran et al., 1996; Timmons, 1999).

Although the literature has indicated a potential firm size effect in levels of formal training (e.g. Castany, 2010; Blundell et al., 1999; Baldwin et al., 1995), there is an absence of empirical studies that have examined the effect of recession on the training and development practices applied by firms of different sizes. While employees in large firms are more likely to benefit from formal training development opportunities (Wickramasinghe and 
Perera, 2012), it is likely that such expenditure might be cut during recession. As training in SMEs may be more informal, unplanned, reactive, and short-term oriented and less costly (Hill and Stewart, 2000; Curran et al., 1996), we hypothesise that:

H5: Large firms are more likely than small firms to reduce their expenditure on formal training and development.

Another potential HR response of firms facing a decline in demand and poor performance is reducing employee benefits (Giancola, 2009). As with formal training and development, availability of fringe benefits and rewards, both monetary and non-monetary, are associated with the size of the organisation (Edmiston, 2007). Such benefits are much more common in larger firms which have the resources, knowledge, expertise, and desire to introduce and administer them (Kroon et al., 2012; Bacon and Hoque, 2005). Nevertheless, under adverse economic conditions there may be pressure to review and potentially cut costs associated with employee benefits (Latham, 2009; Shama, 1993). In contrast, in SMEs informal rewards and recognition are more prevalent, and this is why we might anticipate less impact of the recession on formal fringe benefits and rewards in smaller firms. Hence, we hypothesise that:

H6: Large firms are more likely than small firms to reduce fringe benefits and rewards.

Finally, we might expect that temporary contract and agency workers are more likely to be released by employers when implementing retrenchment strategies (Green, 2008). By definition, temporary workers experience higher levels of employment insecurity (OECD, 2009; Booth et al., 2002). For instance, Green (2008) shows that half of the temporary workers surveyed believed that they would be laid off and become unemployed within a year, compared with $85 \%$ of permanent workers. Again, there is a positive relationship between firm size and the use of agency labour or temporary workers (Forde and Slater, 2006; Hunter and MacInnes, 1991), with outsourcing and use of agency workers for any tasks or function relatively rare in small firms (Fry and Blundel, 2013). It is therefore hypothesised that:

H7: Large firms are more likely to make a change in the use of temporary or agency workers than small firms.

As shown in Storey et al. (2010), management formality is associated with firm size (also see Saridakis et al., 2013; Forth et al., 2006; Kotey and Slade, 2005); HR formality 
increases as firm size increases. To extract a pure size effect related to our hypotheses developed above, we follow the work by Tsai et al. (2007) and thus, control for HR management formality in our specification. The literature, however, shows that small firms adopt limited HRM strategies to withhold the uncertainties associated with the economic shock (see, for example, Bidya, 2009; Mohrman and Worley, 2009; Katzenbach and Bromfield, 2009). Wickramasinghe and Perera (2012) suggest that firms with formalised work practices and procedures have more structured systems and processes in managing its personnel than those with low HRM formality and professionalism when facing the economic shock. This is possibly because of the availability of a larger pool of HR knowledge and expertise in the former firms. Use of a wider range of formal HR practices in larger firms may also instigate a structured review of the desirability and sustainability of these practices in times of recession, compared with the inherent flexibility and informality more typical in small firms. In short, given larger firms are likely to have more formal policies as well as employee expectations concerning these policies, we anticipate a desire to review these policies in times of economic hardship. We therefore hypothesise that:

H8: Firms with formal HR practices are more likely to take employment related actions during the recession.

\section{Research methodology}

\subsection{Dataset}

In order to explore the impact of recession on firms and their employees in different sizes of organisations, we use data from WERS2011. This is the sixth ${ }^{1}$ in a Government funded series of a national representative, cross-sectional survey undertaken in the UK in 2011. It collected a wide range of information regarding employment relationships from managers, employees and their representatives. The survey population for WERS2011 is all workplaces with 5 or more employees in the British economy, excluding those in agriculture, forestry, fishing, and mining and quarrying. The economic and social context for the 2011 WERS provides a unique opportunity to explore how firms have responded to an economic downturn and how businesses and their workers have been affected (Wells, 2013). The sample comprises of

\footnotetext{
${ }^{1}$ The previous five WERS were undertaken in 1980, 1984, 1990, 1998 and 2004. The fieldwork for the sixth WERS (WERS 2011) took place from March 2011 to June 2012.
} 
22,738 employees (response rate $=54 \%$ ) from 2,680 workplaces (response rate=46\%), including 3,063 employees from 531 small organisations, 2,878 employees from 338 medium firms and 16,797 employees from 1,811 large organisations. The WERS2011 has four main sections, and the present study focuses on Management Questionnaire and Employee Questionnaire. $^{2}$

\subsection{Dependent variables}

\subsubsection{Measuring the impact of recession on firms}

The 2011 WERS covers only two questions in the Management Questionnaire to identify how surviving firms have been affected by the latest economic downturn. They are 'To what extent were firms adversely affected by the recent recession?' and 'The firm is now weaker because of its experience in the recent recession?' ${ }^{3}$ The response for the former question is evaluated on a five-point likert scale, 1-'no adverse effect', 2-‘just a little', 3-'a moderate amount', 4-'quite a lot' or 5-'a great deal'. The responses for the latter measure is also examined on a five-point likert scale, 1- 'strongly disagree', 2- 'disagree', 3-'neither agree nor disagree', 4-'agree’ or 5-'strongly agree’. These two dependent variables are used to test our hypothesis H1.

\subsubsection{Measuring employment related actions taken by firms in response to the recession}

A substantial proportion of surviving firms have taken at least one form of retrenchment action that impacts directly on their workforce in order to survive the recession. In total, 13

\footnotetext{
${ }^{2}$ The other two sections are Employee Representative Questionnaire and Financial Performance Questionnaire.

${ }^{3}$ The 2011 WERS include these two questions to identify which surviving firms had been affected by the downturn, but it did not clearly state the exact impact of economic crisis on firm performance, such as overall performance and profitability. However, WERS2011 did ask managers regarding the financial performance and labor productivity against the overall industry performance. The responses were evaluated on a five-point Likert scale, 'a lot better than average', 'better than average', 'about average for industry', 'below average' or 'a lot below average'. We find that manager respondents that answer ' $n o$ ' ( $67 \%$ and $66 \%$, respectively) and 'a little' ( $71 \%$ and $67 \%$, respectively) to the question 'To what extent were firms adversely affected by the recent recession?' are also more likely to respond to 'a lot better than average' and 'better than average' categories of firm performance (financial performance and labor productivity, respectively). Similarly, manager respondents that answer 'strongly disagree' (68\% and $73 \%$, respectively) and 'disagree' ( $56 \%$ and $55 \%$, respectively) to the question 'The firm is weaker now due the recent recession' are also more likely to respond to 'a lot better than average' and 'better than average' categories of firm performance (financial performance and labor productivity, respectively).
} 
employment related adaptations were presented to managerial respondents. They were 'compulsory redundancies', 'voluntary redundancies', 'temporary freeze on recruitment to fill vacancy', 'postponement of plans for expanding the business', 'freeze or cut in wages', 'reduction in non-wage benefits', 'reduction in basic hours', 'reduction in paid overtime', 'employees required to take unpaid leave', 'reduction in the use of agency staff or temporary workers', 'increase in the use of agency staff or temporary worker', 'reduction in training expenditure' and 'change in the organisation of work'. The responses are examined on a dichotomous scale: 1-‘yes’ or 0-‘no’ and are used to test hypotheses H2-H7.

\subsubsection{Measuring the changes experienced by the employees as a result of recession}

The WERS2011 asks employees if they have experienced any of nine specified changes as a result of the recent recession. They include 'wages frozen or cut', 'workload increased', 'work was reorganised', 'access to paid overtime restricted', 'access to training restricted', 'non-wage benefits reduced', 'moved to another job', 'contracted working hours reduced' and 'required to take unpaid leave'. Responses were evaluated on a dichotomous scale: 1'yes' or 0-‘no'. These variables are used to examine the potential difference between HR practices described and adopted by managers to those experienced by small and large firm employees, to evaluate further the relevance of hypotheses H2-H7.

\subsection{Independent variables}

\subsubsection{Measuring firm size}

We construct firm size that meets the standard European enterprise size definition: firms with less than 50 employees are defined as small, those have 50-249 employees as medium, and those have 250 or more employees as large enterprises (European Commission, 2003). Although the WERS data includes information on size of workplace ${ }^{4}$, it also identifies workplaces with both single-site and multi-site enterprises and asks the total number of employees in the whole organisation (or enterprise) of which the workplace is a part of (see

\footnotetext{
${ }^{4}$ The 'workplace' is defined as comprising 'the activities of a single employer at a single set of premises', and can include, for example, a branch of a high street bank, or a single-site factory. More information is available in the report titled The Design and Administration of the 2011 Workplace Employment Relations Survey (August 2013).
} 
Saridakis et al., 2013). Our matched employer-employee data comprise 7,168 employees from 900 privately-owned firms. ${ }^{5}$

We disaggregate by size of firm to capture potential differences between smaller and larger firms but also amongst SMEs. Research has shown that there is important heterogeneity amongst SMEs in terms of management of employees, organisational structure and process, strategic planning, external inputs, financing methods, customer base, employment development and the availability of funding sources (ICAEW and BDO Stoy Hayward, 2005; Blackburn, 2012). Interestingly, the organisational characteristics of medium-sized firms tend to be closer to their large counterparts rather than smaller ones. For example, medium-sized firms have a wider range of financing options, customer base and external inputs, and managed in a more formalised, professionalised and structured manner, but in a less degree in comparison to large firms (M Institute, 2006). It is expected that medium-sized firms are probably more resilient than their small counterparts but relatively more vulnerable than their large counterparts. Regarding the strategic responses to the threats of the recession, mediumsized firms may be rather more like large firms in terms of the choice of HRM adaptations and the extent of using them. Hence, it is important to spilt the whole SMEs population into two sub-groups -small firms and medium ones, and investigate whether any significant diversions exist within the SMEs grouping itself. This key independent variable is included in our specifications to test all our hypotheses related to firm size.

\subsubsection{Measuring HR formality}

Boselie et al. (2005) suggest that HRM can be viewed as a collection of multiple, discrete practices with no explicit or discernible link between them, or as a more strategically minded systems approach that HRM is an integrated and coherent 'bundle' of mutually reinforcing practices. Similar to the majority of the research, we use the former approach to generate an index of possible HR policies, and check how many were used by the sampled firms. In particular, HR formality is measured in line with Storey et al.'s (2010) and Saridakis et al.'s (2013) work. They are also consistent with the type of HR processes and strategies proposed by Edwards and Ram (2009) in their discussion of indices of HR formality in relation to

\footnotetext{
${ }^{5}$ Due to the missing values, the total number of observations included in the present study is reduced. Also, only those employees who were working in the current company during the recession are included in the present study.
} 
earlier Workplace Employment Relations Surveys in Britain. In total, 12 HR formal policies drawn from the Management Questionnaire were used, including "presence of a person mainly concerned with HR issues”, "existence of a formal strategic plan”, “accredited as an Investor in People”, "presence of a standard induction programme”, "procedure for dealing with discipline and dismissals”, "a formal written policy for an equal opportunity policy”, “a formal procedure for dealing with a grievance procedure", "presence of a formal target", "any performance appraisal”, “any non-payment benefits”, "any meetings between management and the whole workforce" and "presence of any formal communication channels between management and employees". Responses to these questions are all measured on a binary scale: “yes” (1) or “no” (0). An overall HR formality score is created after calculating the Cronbach's alpha $(\alpha=0.76)$, ranging from $0-1$. The HR formality variable is included in the regression estimations to allow for separate effects of firm size (hypotheses H1-H7) and formality (hypothesis H8).

\subsubsection{Other control variables}

Following previous work using WERS data (e.g. Saridakis et al., 2013; Wickramasinghe and Perera, 2012; Storey et al., 2010; Brown et al., 2010) we control for a wide range of employee (e.g. gender, age, ethnicity, education, long-term illness) and firm characteristics (e.g. trade union presence, industry, degree of competition) in our analysis and pick up their effects. Summary statistics of the variables used in the regression analysis are presented in Table A1 in Appendix. For brevity, we omit to discuss the full results and focus our discussion mainly on our key independent variables that are firm size and HR formality.

\subsection{Descriptive analysis}

\subsubsection{The impact of recession on firms}

Table 1 presents the responses to each measure on the impact of the recent recession in SMEs. For those that have been adversely affected, we note that the recession had 'a great deal' of negative effect on more than one-fifth small firms (22.5\%), compared with only $12.2 \%$ of medium-sized and $14.0 \%$ of large sized firms. Regarding the second measure that 'the firm is weaker because of its experience in the recent recession', the results show that the proportion 
of managers in small firms (21.5\%) that believe the recession had weakened their company (cf 'agree' and 'strongly agree' response category) is greater than that in both medium (13.7\%) and large firms (13\%). Overall, the results suggest that not only has the recession had a significantly different impact between the small and large firms, but there is also a differential effect within the SMEs population.

[Table 1 here]

\subsubsection{HRM policies taken by firms in response to the recession}

Table 2 presents the weighted proportion of each employment related action taken by size of firms: $26.9 \%$ of small firms have not taken any form of action, compared with $21.8 \%$ of large organisations. Amongst those smaller firms that have taken employment related adaptations, three actions appear to be prevalent. Freezes or wage cuts are the most common approach used by both small and medium firms: $43.4 \%$ and $44.1 \%$ of them have taken this measure compared with only $31.6 \%$ of large firms. Also, the recession has promoted a reduction in basic work hours in $13.3 \%$ of small firms, while only $10.5 \%$ of large firms have seen this form of action. Given the lower presence of trade unions in small firms, their employees may have limited influence and power in terms of concession bargaining or negotiating reciprocal advantages, having to accept reduced pay or short-term working, and this may facilitate the use of such strategies (Acas, 2009). In addition, their lower levels of formalisation and bureaucracy may enable more flexible and informal working conditions in response to sudden economic uncertainties (Broughton, 2011). Using three different samples of firms, employees and workplaces in the UK, Crawford et al. (2013) suggest that through cutting wages and/or hours rather than workforce headcount during the recent recession, small firms are more able to reduce labour costs, per employee, than large firms. This has the advantage of avoiding incurring recruitment and additional training costs in a subsequent expansion. Postponement of plans for expanding the business is the third action that is more likely to be adopted by small (24.2\%) and medium (29.2\%) than large firms (22.7\%), indicating that the small firm sector is more constrained in the adoption of an enabling approach during the crisis. This may be due to their lack of financial resources and the difficulty in achieving scale and scope economics compared with those of large firms (Cowling et al., 2012; Kitching et al., 2009a). 
On the other hand, large firms are more likely than small and medium firms to reduce workforce size by making redundancies. In particular, the larger the firm, the greater possibility that voluntary redundancies have taken place (small firms: $4.5 \%$, medium firms: 11.9\% and large firms: $22.8 \%$ ). Hence, as the literature suggests, smaller firms appear to be retaining staff and adjusting their hours rather than creating redundancies. For micro-firms, this may be because they have to keep a minimum number of staff in order to operate, whereas in large firms the greater number of employees allows for redundancies. As expected, fringe benefits or rewards are more likely to be cut in large firms than their smaller counterparts. These are shown in the higher incidence of a larger employers having 'reduction in non-wage benefits', 'reduction in paid overtime' and 'employees are required to take unpaid leave'. Likewise, changes in the use of agency staff (either increase or decrease) are more likely to take place in large firms than small firms. Large firms are also more likely to reduce training expenditure, and change the organisation of work. Overall, we observe a difference between small and large firms in a majority of HRM adaptations (eight out of thirteen actions, see Table 2), whereas the differentiation between small and medium firms, as well as between medium and large firms, are rather insignificant in most cases.

[Table 2 here]

\subsubsection{Changes in the employees' work experience as a result of the recession}

Table 3 presents the weighted proportion results of each change employees experienced by organisation size. For employees who report being adversely affected by the recession and experienced negative changes in work, the evidence shows that the pattern of the responses for each change differs significantly by firm size. The likelihood for employees to experience the majority of changes as a result of recession increases with firm size (except 'wages frozen or cut' and 'contracted working hours reduced'). More specifically, employees in small firms are least likely to experience changes at work as a result of employer responses to the recent recession, followed by those in medium-sized firms, and those in large firms. However, small firm employees are more likely to experience wage cuts or a pay freeze (27.3\%) than those in large organisations (22.1\%). We also observe that workers in small firms (8.6\%) are more likely to report that their contracted hours have been reduced than those in large firms (3.3\%). Comparing the changes described in employees' work experience with the employment 
related actions taken by firms (see Table 2), we find six matches (i.e. 'freeze or cut in wages', 'reduction in non-wage benefits', 'reduction in basic hours', 'reduction in paid overtime', 'take unpaid leave' and 'reduction in training expenditure'). More importantly, all six changes that employees have experienced because of employer responses to the recession corresponds to the respective HRM policy stated by the managers, suggesting no contradiction with respect to HRM managers’ and employees’ perspectives.

[Table 3 here]

\section{Regression analysis}

The literature discussed earlier (see section 2.1) suggests that the manner in which a recession impacts on a firm and the firm's strategic responses to the threats of economic downturn, is not simply a function of firm size. Rather, the effect of a recession on a firm is a result of the interaction of internal and external factors, including the size of the firm. Hence, we continue the analysis by using an ordered probit regression and a probit regression, to test the statistical association amongst firm size, HR formality and the dependent variables, controlling for the factors that may also shape the effect of the recession on the firm and employees' experience of work during recessions, manifested in a wide range of employee and firm characteristics (see Table A1 in Appendix).

Table 4 presents the coefficient results for the impact of recession on the firm. ${ }^{6}$ The results show that after controlling for individual and firm characteristics, large firms are less likely than medium sized firms to be adversely affected from the recession. ${ }^{7}$ Also, when we compare SMEs as a whole with large firms (results are available upon request) the results

\footnotetext{
${ }^{6}$ We checked the robustness of the estimation results by using the ordered logistic regression, and the results are similar (results are available upon request). Also, we estimated the models by including the interaction between 'at least one form of action was taken' and formalised HRM policies. The coefficient results for the interaction in all models are statistically insignificant, suggesting that the level of HRM formality does not moderate the relationship between actions taken in response to the recession by the firm and the impact of recession on the firm. Finally, we use propensity score matching as a method (see Becker and Ichino, 2002), given the fact that firms that have been adversely affected, or are weaker because of the experience in the recession, may be more likely to take actions. We used the nearest neighbour matching to estimate Average effect of Treatment on the Treated (ATT). The probability differences (ATT) in the outcome (Measure 1) between the treated and controls is 0.820 , at significant level $1 \%$. The difference in the outcome (Measure 2) is 0.258 , at the significant level of $1 \%$. ${ }^{7}$ Although the results are not shown here, we find that trade union member employees are less likely to be adversely affected by recession whereas permanent workers are more likely to be adversely affected by recession. Firms that are competing in mature and growing market are less likely than those in turbulent markets to be negatively affected by the recession. Additionally, in our models we observe industry effects.
} 
suggest that large firms are less likely to be adversely affected by the recession. The results also show that the possibility that a firm is weaker now, as a result of recession, decreases with firm size. Overall, the results provide support for hypothesis H1.

\section{[Table 4 here]}

Table 5 reports the multivariate results of each individual HRM action taken by firms in response to the recession. ${ }^{8}$ In most cases, small firms (with less than 50 employees) are less likely than large firms to take actions that have a direct impact on employment numbers, including making 'compulsory redundancy', 'voluntary redundancy' and 'temporary freeze on recruitment to fill vacancy'. Therefore, hypothesis H2 is fully supported. In addition, the significant and negative coefficients for small firms suggest that they differ greatly from large firms in terms of reducing employees’ basic hours. More specifically, they are less likely than their larger counterparts to reduce employees' basic work hours in response to the recession. Hence, hypothesis H3 is rejected. The coefficient for small firms, on the other hand, is statistically significant and positive for having a wage freeze or cut, indicating that the possibility of freezing or cutting in employees' wages in these firms is higher than that in large firms. This is consistent with the proportion outcomes (see Table 2). Hypothesis H4 therefore is supported. Finally and in line with the descriptive results shown in Table 2, we find that small firms are less likely than their larger counterparts to reduce fringe benefits and rewards ('reduction in paid overtime' and 'employees are required to take unpaid leave'), to reduce or increase 'the use of agency staff or temporary workers' and to make a 'reduction in training expenditure'. Hence, hypotheses H5, H6 and H7 are all supported. ${ }^{9}$

The coefficient results for HR formality also show that as HR formality increases, the possibility that the majority of the HRM adaptations (except 'reduction in non-wage benefits', 'reduction in basic hours', 'employees required to take unpaid leave' and 'increase in the use of agency staff or temporary worker') would take place as a result of the recession increase accordingly. Overall, hypothesis H8 is supported. Given the general understanding that HR formality increases with firm size (Storey et al., 2010; Kersley et al., 2006; Nguyen and Bryant, 2004), our findings suggest that larger firms with high levels of formalisation tend to

\footnotetext{
${ }^{8}$ Also, our coefficient results (estimation w.r.t Table 5) show that firms that have trade union employees, female workers, employees with university degree and supervisory responsibility are less likely to take the majority of the actions. Firms that are competing in declining, mature and growing market are less likely than those in turbulent market to take all listed employment related actions. We also find differences across industries.

${ }^{9}$ We checked the robustness of the estimation results by using the logistic regression, and the results are similar (results are available upon request).
} 
take more actions that can directly affect employment and the internal structure of the organisation.

[Table 5 is about here.]

Table 6 presents the estimated coefficients of each individual change experienced by employees because of the recessionary conditions. ${ }^{10}$ Employees in small firms are more likely to experience a 'freeze or cut employees' wages' and 'reduce their contracted hours' than large firms: This further supports hypotheses H3 and H4. Perhaps workers in small firms experience a reduction in working hours in an informal setting and this is captured by the employee reported as an experience rather than the formal strategy reported by the employer (see Table 5). ${ }^{11}$ The possibility that the fringe benefits and rewards represented by three questions including 'My non-wage benefits were reduced', 'Access to paid overtime is restricted' and 'I was required to take unpaid leave', increases as the workforce size expands, further confirms support for hypothesis H6. Usually, better working conditions, including superior fringe benefits, higher pay levels, relatively generous time-off benefits and better career development prospects, are associated with high formality and are more likely to be available to employees in larger organisations (Hoque and Bacon, 2006; Idson and Oi, 1999). However, as one of the most significant exogenous shocks to a firm's viability and continued profitability (Mascarehas and Aaker, 1989), a recession may force these organisations to cut generous discretionary benefits and rewards that are available to employees during stable and growth periods, and thus their employees may be more prone to fringe benefit and reward reduction. Additionally, it may be that small firms use more informal practices and thus less active in taking actions in response to recession because they have less scope, or perceived need, to reduce monetary and non-monetary benefits for their employees.

[Table 6 is about here.]

\footnotetext{
${ }^{10}$ Regarding the changes experienced by the employees as a result of the recession, our coefficient results (estimation w.r.t Table 6) show that employees with university degree, have supervisory responsibilities and offer higher wage are more likely to experience almost all negative changes at work due to the recession; where female workers are less likely to experience the changes. Also, employees that work for firms that are competing in mature and growing market are less likely to experience the majority of changes in work as a result of the crisis. Finally, we find industry effects.

${ }^{11}$ Another explanation may be that the employees do not represent all occupational groups; whereas the manager respondents are responsible for employee relations in the whole establishment, and therefore their responses given for each action taken in response to the recession refer to the whole workforce.
} 


\section{Conclusion and implications}

This article has investigated the impact of the recent economic downturn on firms, their HRM policies and practices in response to the recession, and the changes in employees' experience of work. Overall, we might expect a decline in economic activity to lead to a reduction in demand at the organisation level, and in turn a fall in demand for labour. However, specific organisational responses to this environment are likely to depend partly upon factors including national context, sector, management strategy and market conditions. In this paper, we focus on another important variable - size - and examine whether there are any differences by size of firm: small, medium and large. In particular, this paper sheds more light on the impact of the recession on different sized firms and subsequent HR responses undertaken by managers/owners and experienced by small and large firm workers.

Based on Smallbone et al.'s (2012) dualistic view with regard to how firms of different size are affected by the recession, we find that the economic downturn of 2008/9 has had a deeper adverse impact on the SME population as a whole, than it did on large firms. However, once we unpack SMEs into small (less than 50 employees) and medium sizedenterprises (50-249 employees), we find evidence that medium sized enterprises show more resilience than smaller firms. These findings add support to the view that substantial heterogeneity exists in the SME business population (Hurst and Pugsley, 2011), but also confirms that firm size generally matters during tough times. Existing analyses have proposed that the characteristics of smaller firms can be potentially advantageous, allowing small firms to respond quickly and flexibly, as well as disadvantageous, such as their 'dependent position' (Rainnie, 1989) and limited resources. On balance, our study lends support to the latter view, as smaller firms appear to have more affected by and vulnerable to the recession.

In response to the challenges posed by the recession, the majority of surviving British firms chose a strategy of retrenchment (Kitching et al., 2009b). This involves a variety of HRM strategies to reduce labour costs, such as downsizing, freezing wages and reducing work hours, rather than seeking revenue generating opportunities or by maintaining or expanding the size of workforce. Importantly, our findings also suggest the extent to which each possible specified form of action is significantly associated with firm size (see Storey et al., 2010; Marlow, 2005; Kotey and Slade, 2005; Storey, 2002). It seems that large firms are more likely to lay off workers than SMEs, with a greater proportion of large firms introducing compulsory and voluntary redundancies or freezing recruitment. Small firms, on the other 
hand, have tended to use cost-cutting by focusing upon pay, with freezing or reducing wages more common in SMEs than in large organisations. Pay cuts may be a consequence of more informal HR where pay rises are more discretionary and flexible compared to large organisations where pay is set through formal HR structures and employment relations institutions (such as trade unions and collective bargaining) (Marlow et al., 2005; Broughton, 2011). The individualised nature of the employment relationship generally, and of reward setting specifically, may mean smaller firms have more flexibility in reducing pay than large firms. Alternatively, introducing pay cuts may simply be viewed as essential for survival.

However, we also find that certain cost-cutting practices are more evident in large organisations. These include reductions in discretionary and fringe benefits (e.g. non-wage benefits, paid overtime and unpaid leave, formal training expenditure), and reductions in the use of agency staff or temporary workers. This seems to correspond to the pre-existing lower levels of fringe benefits available to employees in small organisations (Kitching and Marlow, 2013; Dekker and Barling, 1995), lower expenditure on training and development activity, and lower use of agency and temporary staff. Our findings thus also provide some evidence to support the view that large firms may adopt a wider range of cost-reduction strategies than small firms (e.g. Latham, 2009; Shama, 1993). This might be because crisis encourages a detailed review of all formal HR practices and labour-related costs in large organisations, and larger organisations generally have more formal activities to officially cut or modify compared with the informal and perhaps more ad hoc policies and practices of their smaller counterparts. The presence of a professional HR function may also make such a review of how the organisation might 'slim down' feasible, as well as creative ideas about how this might be achieved, as well as awareness of the HR responses of other organisations.

In examining the effect of recession-related effects on employees' experience of work, we find that changes in employees' experience of work also vary significantly by firm size. The majority of negative changes in employees' work experience increases with organisation size, including 'workload increased', 'work is re-organised', 'non-wage benefits were reduced', 'access to paid overtime was restricted', 'require to take unpaid leave' and 'access to training was restricted'. Overall, these findings indicate that workers in large firms report a more wide-ranging impact of the economic crisis than those in smaller organisations. This might reflect the fact that such turbulence and official policy changes are more keenly felt in large organisations, with formal policy commitments and different employee expectations. 
The results also show that firms with formalised HR practices are more likely to take actions that have a direct impact on employment than those with informal work practices.

Finally, we find a consistent response pattern between managers' and employees' responses with respect to the three matched HRM policies adopted during the period of 2008/9 recession. This consistent response includes reduced working hours, wage frozen or cut, reduced fringe benefits and reduced expenditure in training. These findings are particularly interesting given the fact that most of the existing work focuses on managers' perspectives (see Cowling et al., 2014; Smallbone et al., 2012; Kitching et al., 2011) rather than on employee' views and experience. Indeed, the impact of developing and implementing HRM strategy is relevant to both employees and managers (Guest, 1999). Last but not least, our analysis also suggests that the impact of the recession on firms and their HRM responses are associated with certain employee and organisational characteristics. These include trade union membership, gender, education, supervisory responsibilities, the current state of the market, the degree of competition and the industry.

This analysis has implications for theory and practice. Regarding the contribution to theory, there are surprisingly few studies that examine the effects of recession by size of enterprise and in particular, the HRM strategies adopted by firms of different size. This is important given the fundamental difference in the nature of employment relations and people management practices between firms of a different size (Kitching and Marlow, 2013). Hence, we draw our analysis from the latest WERS 2011 survey which provides data from surveys of employers and employees.

More broadly, Giancola (2009) notes that few studies have explored how firms respond to recession, and how these reactions affect the work experience of employees. While the existing literature has suggested a potential difference in management of HRM between SMEs and large firms, this is normally in times of economic stability and growth. However, it also useful to unpack such issues further during a period of economic downturn. Our study thus builds upon the few studies which have begun to tackle this issue (e.g. Latham, 2009), and contributes to the limited existing body of knowledge (e.g. Wickramasinghe and Perera, 2012). Our findings reveal that larger organisations tended to make changes to a broader range of HR priorities, including freezing recruitment, making redundancies, reducing working hours, reducing expenditure on formal training and employee benefits, and making changes in the use of temporary labour. Smaller firms, however, appear more constrained in 
their range of options, tending instead to freeze or reduce pay. Smaller firms are, therefore, not only more vulnerable to recession, but also have - or opt for - a narrower range of HR changes. In part, this might reflect that SMEs had fewer options available to them. Overall, this supports the view that small firms are not simply 'little big firms' (Welsh and White, 1981), and that SMEs encounter particular HR challenges during both periods of economic stability and volatility. This reinforces the need for further research at the intersection of HRM and entrepreneurship to help develop our understanding of business challenges, management responses, and employee responses in smaller firms. We hope our study will stimulate some further research in this potentially fruitful area.

For practitioners and policy makers, it has been acknowledged that the small business sector is a vital component of UK economy and growth (Department for Business Innovation and Skills, 2009; Matlay, 2012). The evidence here shows that many smaller firms, in particular those with 5-49 employees have been struggling during the recent recession and their anticipated continued growth and contribution to the economic recovery can be problematic. It also suggests the range of HR choices available may be limited. Furthermore, the heterogeneity, diversity and complexity make generalisations about SMEs, their experiences and responses to recession problematic. It seems no simple 'one size fits' policy prescriptions will help them survive or thrive when faced with tough economic conditions. Our main policy recommendation, therefore, is for more attention to be paid to the distinctive challenges of managing human resources in smaller firms, given their vulnerability, distinctiveness, and limited resources.

Our analysis also has implications for further studies. We use the number of employees as a proxy for firm size. However, further research may benefit from a multidimensional approach to the concept of size (e.g. total assets, total sales or revenue). Our findings suggest that smaller firms are more sensitive to external shocks (in this case are more vulnerable to and affected by recessionary conditions) than larger firms. However, further research may investigate whether the same outcome applies to small businesses during an economic boom (that whether small firms are more likely than large firms to experience growth when upswing comes). In addition, recessions have uneven effects on different industries, sectors and regions of the country, which simultaneously shape the diversity of experience of recession and business responses along with the business size (Smallbone et al., 
2012; Kitching et al., 2011; Athey, 2009). Also, results may vary across countries operating in different labour market conditions. These issues may also merit further research.

Finally, all empirical studies have limitations and ours is no exception. While a key strength of the WERS is that the breadth of the information collected allows the compilation of a picture of workplace employment that goes well beyond the concerns of traditional industrial relations research (Colvin, 2011), the analysis is limited by the parameters of the data collected. In particular, it is important to note that employers with 1-4 employees are not in the analysis. In addition, it is difficult to test the impact of different kind of ownership in relation to selecting HRM practices and policies, given that limited information is collected on this matter. In particular, family-owned businesses are generally considered to adopt more informal HRM practices, and may have an impact on our findings, and there is also diversity amongst family businesses regarding their approach to HRM. However, developing our understanding of the heterogeneity of HR practices and processes in small firms is likely to require qualitative investigations. These would help us understand how and why HR decisions are made and further explain heterogeneity in a context of informality. 


\section{References}

Acas (2009). The Recession: What the Future Holds for Employment Relations. Acas Policy Discussion $\quad$ Papers, June Available at: http://www.acas.org.uk/media/pdf/8/6/policy-paper-recession-accessible-version-July2011.pdf. Retrieved on 11 November, 2013.

Akerlof, G.A. (1982). Labor contracts as partial gift exchange. Quarterly Journal of Economics, 97, pp.543-569.

Aldrich, H. and Langton, N. (1997). Human resource management practices and organisational life cycles. In Frontiers of Entrepreneurship Research. ( eds) Reynolads, P.D., Bygrave, W.D., Carter, N.M., Davidsson, W., B., Bartner, C., Mason, C. and McDougall, P.P. Wellesley, MA: Babson College Centre for Entrepreneurship. pp. 349-357.

Anderson, A. and Russell. E. (2009). Small business in economic adversity: Impact, affect and responses. Paper presented at Institute for Small Business and Entrepreneurship Conference November, Liverpool.

Artz, B. (2008). The role of firm size and performance pay in determining employee job satisfaction brief: Firm size, performance pay and job satisfaction. Labour, 22(2), pp.315-343.

Athey, G. (2009). Economic development in the UK: Challenges during and after the recession. Local Economy, 24(6-7): pp604-611.

Auerswald, P.E. and Branscomb, L.M. (2003). Valleys of death and Darwinian seas: Financing the invention to innovation transition in the United State. Journal of Technology Transfer, 28(3-4), pp.227-239.

Bacon, N. and Hoque, K. (2005). HRM in the SME sector: valuable employees and coercive networks. International Journal of Human Resource Management, 16(11): pp.19761999.

Baldwin, J.R., Gray, T. and Johnson, J. (1995). Technology use, training and plant-specific knowledge in manufacturing establishments. Working paper, 86, Microeconomics Analysis Division, Statistics Canada, Ottawa.

Baron, R. (2003). Editorial: Human resource management and entrepreneurship: Some reciprocal benefits of closer links. Human Resource Review, 13, pp.253-256.

Barrett, R. and Mayson, S. (2006). Exploring the intersection of HRM and entrepreneurship. Guest editors' introduction to the special edition on HRM and entrepreneurship. Human Resource Management Review, 16, pp.443-444.

Becker, S.O. and Ichino A. (2002). Estimation of average treatment effects based on propensity scores. Statistic Journal, 2, pp.358-377.

Bednarzik, R. (2000). The role of entrepreneurship in US and European job growth. Monthly Labour Review, 123(3): pp. 3-16.

Bewley, T.F. (1999). Why wages do not Fall during a Recession. Harvard University Press, Cambridge, MA.

Bidya, D. (2009). A study on performance management through recession metrics during downturn. Advances in Management, 2(10), pp.27-30.

Binks, M., Ennew, C. and Reed, G. (1992). Information asymmetries and the provision of finance to small firms. International Small Business Journal, 11(1), pp35-47.

Blackburn, R. (2012). Segmenting the SME market and implications for service provision: a literature review. Advisory, Conciliation and Arbitration Service, ACAS, London.

Blundell, R., Crawford, C. and Wenchao, J. (2013). What can wages and employment tell us about the UK's productivity puzzle. Working Paper No. 13/11, Institute for Fiscal Studies. 
Blundell, R., Dearden, L., Meghir, C. and Sianesi, B. (1999). Human capital investment: the results from education and training to the individual, the firm and the economy. Fiscal Studies, 20(1), pp.1-23.

Booth, A.L., Francesconi, M. and Frank, J. (2002). Temporary jobs: Stepping stones or dead ends. Economic Journal, 112(480), pp. F189-F213.

Boselie, P., Dietz, G. and Boon, C. (2005). Commonalities and contradictions in HRM and performance research. Human Resource Management Journal, 15(3), pp67-94.

Broughton, A. (2011). SMEs in the Crisis: Employment, Industrial Relations and Local Partnership. European Foundation for the Improvement of Living and Working Conditions. Available at:

Brown, S., McHardy, J., McNabb, R. and Taylor, K. (2010). Workplace performance, worker commitment, and loyalty. Journal of Economics and Management, 20: pp.925-955.

Brundage, H. and Koziel, M. (2010). Retaining top talent still a requirement for firms. Journal of Accountancy, 209(5), pp. 38-44.

Cable, V. (2009). The Storm: The World Economic Crisis \& What it Means. Atlantic Books: London.

Carr, J.C., Topping, S., Woodard, B. and Burcham, M. (2004). Health care entrepreneurship in the Nashville region: Societal linkages, change dynamics, and entrepreneurial responses. Journal of Applied Management and Entrepreneurship, 9(1): pp. 49-64.

Cassell, C., Nadin, S., Gray, M. and Clegg, C. (2002). Exploring human resource management practices in small and medium sized enterprises, Personnel Review, 31(2), pp671-692.

Castany, L. (2010). The role of size in firms' training: Evidence from Spain. International Journal of Manpower, 31(5), pp.563-584.

Chandler, G. and McEvoy, G. (2000). Human resource management, TQM and firm performance in small and medium-sized enterprises. Entrepreneurship Theory and Practice, 25(1), pp.43-58.

Child, J. (1972). Organisation, structure, and strategies of control: A replication of the Aston study. Administrative Science Quarterly, 17(3), pp.163-177.

Chow, M.J. and Dunkelberg, W.C. (2011). The small business sector in recent recoveries. Business Economics, 46(4), pp.214-228.

CIPD. (2009). Employee Outlook: Working Life in a Recession. Quarterly Survey Report, Autumn, 2009. London: CIPD.

Colvin, A. (2011). Review of the book the evaluation of the modern workplace. British Journal of Industrial Relations, 49(3), pp.583-586.

Comin, D., Groshen, E.L. and Rabin, B. (2008). Turbulent firms, turbulent wages? Journal of Monetary Economics, 56 (2009), pp.109-133.

Cowling, M., Liu, W. and Ledger, A. (2012). Small business financing in the UK before and during the current financial crisis. International Small Business Journal, 30(7), pp.778-800.

Cowling, M., Liu, W., Ledger, A. and Zhang, N. (2014). What really happens to small and medium-sized enterprises in a global economic recessioin? UK evidence on sales and job dynamics. International Small Business Journal, online version DOI: 10.1177/0266242613512513.

Crawford, C., Jin, W. and Simpson, H. (2013). Productivity, investment and profits during the Great Recession: Evidence from UK firms and workers. Fiscal Studies, 34(2), pp.153177.

Cressy, R. (2002). Funding gaps: A symposium. The Economic Journal, 112(477), pp.F1-F16.

Curran, J. (1996). Small Business Strategy in Warner, M (Ed.). International Encyclopedia of Business and Management. Routledge, London and NY: International Thompson Press. 
Curran, J., Blackburn, R., Kithing, J. and North, J. (1996). Establishing Small Firms’ Training Practices, Needs and Use of Industry Training Organisation. DEFF Research Studies RS17, London: HMSO.

Dabić, M., Ortiz-De-Urbina-Criado, M., Romero-Martinez, A.M. (2011). Human resource management in entrepreneurial firms: A literature review. International Journal of Manpower, 32(1), pp14-33.

Dekker,I. and Barling, J. (1995). Workforce size and work-related role stress. Work and Stress, 9(1): pp45-54.

Department for Business Innovation \& Skills. (2009). The Provision of Growth Capital to UK Small and Medium Sized Enterprises. Department for Business Innovation \& Skills, London.

Earnshaw, J., Marchington, M. and Goodman, J. (2000). Unfair to whom? Discipline and Dismissal in small establishments. Industrial Relations Journal, 31, pp.62-73.

Ebben, J. J. and Johnson, A.C. (2005). Efficiency, flexibility, or both? Evidence linking strategy to performance in small firms. Strategic Management Journal, 26(13): pp1249-1259.

Edmiston, K. (2007). Economic Review, $2^{\text {nd }}$ Quarter, pp.73-97.

Edwards, P. and Ram, M. (2006). Surviving on the margins of the economy: Working relationships in small, low-wage firms. Journal of Management Studies, 43(4), pp.895-916.

Edwards, P. and Ram, M. (2009). HRM in small firms: Respecting and regulating informality. In Wilkinson, A., Bacon, N., Redman, T. and Snell, S. (eds), The Sage Handbook of Human Resource Management, London: Sage. Pp.524-540.

Edwards, P., Sam, M., Sen Gupta, S. and Tsai, C. (2006). The structuring of working relationships in small firms: Towards a formal framework. Organisation, 13(5), pp.701-724.

European Commission (2009). European SMEs under Pressure: Annual Report on EU Small and Medium-sized Enterprises 2009. Zoetermeer, The Netherlands: EIM Business and Policy Research.

European Commission, (2003). Commission recommendation of 6 May 2003 concerning the definition of micro, small and medium-sized enterprises. Official Journal of the European Union. L124/36.

Field, S. and Franklin, M. (2013). Micro-data Perspectives on the UK Productivity Conundrum. Office for National Statistics. 20 October 2013. Online at:http://www.ons.gov.uk/ons/dcp171766_295470.pdf

Forbes, D.P. and Milliken, F.J. (1999). Cognition and corporate governance: Understanding boards of directors as strategic decision-making groups. The Academy of Management Review, 24(3): pp489-505.

Forde, C. and Slater, C. (2006). The nature and experience of agency working in Britain: what are the challenges for human resource management? Personnel Review, 35(2), pp.141157.

Forth, J., Bewley, H. and Bryson, A. (2006). Small and Medium-sized Enterprises: Findings from the 2004 Workplace Employment Relations Survey. London: Department of Trade and Industry.

Fotopoulos, G. and Louri, H. (2000). Location and survival of new entry. Small Business Economics, 14(4), pp.311-321.

Fry, J. and Blundel, R. (2013). Job creation and contracting out. Quarterly Survey of Small Business in Britain, Q2, 29(2), June.

Gennard, J. (2009). Editorial - The financial crisis and employee relations. Employee Relations, 31(5): pp451-454. 
Ghemawat, P. (1986). Sustainable advantage. Harvard Business Review, 64(3): pp53-58.

Giancola, F.L. (2009). Wage rigidity during recession. Compensation and Benefits Review, 41(5), pp.27-34.

Gibb, A.A. (1997). Small firms' training and competitiveness: Building upon the small business as a learning organisation. International Small Business Journal, 15(3), pp.13-29.

Green, F. (2008). Temporary work and insecurity in Britain: A problem solved? Social Indicator Research, 88, pp.147-160.

Guardian. (2010). UK recession: Winners and losers. Available at: http://www.theguardian.com/business/2010/jan/26/uk-recession-winners-and-losers. Retrieved on $21^{\text {st }}$ Jan 2015.

Guest, D. (1999). Human resource management - the workers' verdict. Human Resource Management Journal, 9(3), pp.5-25.

Guest, D. (2002). Human resource management, corporate performance and employee wellbeing: Building the worker into HRM. The Journal of Industrial Relations, 44(3), pp.335-358.

Hayton, J.C., Hornsby, J. and Bloodgood, J. (2013). Promoting innovation and entrepreneurship through HR practices. How Can HR Drive Growth? New Horizons in Management Series.

Heneman, R.L., Tansky, J.W. and Camp, S.M. (2000). Human resource management practices in small and medium-sized enterprises: unanswered questions and future research perspectives. Entrepreneurship: Theory and Practices, 25(1), pp.11-26.

Hill, R. and Stewart, J. (2000). Human resource development in small organisations. Journal of European Industrial Training, 24(2), pp.105-117.

Hillier, B. and Ibrahimo, M.V. (1993). Asymmetric information and models of credit rationing. Bulletin of Economic Research, 45(4), pp271-304.

Hoque, K. and Bacon, N. (2006). The antecedents of training activity in British small and medium-sized enterprises. Work, Employment and Society, 20, pp.531-552.

http://eurofound.europa.eu/observatories/eurwork/comparative-information/smes-in-

the-crisis-employment-industrial-relations-and-local-partnership. Retrieved on $21^{\text {st }}$ Nov 2015.

http://www.eurofound.europa.eu/eiro/studies/tn1010039s/tn1010039s.htm. Retrieved on 15 October, 2013.

https://www.gov.uk/government/uploads/system/uploads/attachment_data/file/175479/ 13-535-the-2011-workplace-employment-relations-study-firstfindings1.pdf.Retrieved on 10 October, 2013.

Hunter, L.C. and MacInnes, J. (1991). Employer's Labour Use Strategies - Case Studies. Department of Employment Research Paper 87, London: Department of Employment.

Hurst, E. and Pugsley, B.W. (2011). Understanding small business heterogeneity. National Bureau of Economic Research, working paper 17041. Available online: http://www.nber.org/papers/w17041.

ICAEW and BOD Stoy Hayward (2005). Taking $M$ out of SME: Seven factors making $M$ businesses the powerhouse of Britain's economy. A joint research report by the Institute of Chartered Accountants in England \& Wales and BDO Stoy Haywood.

Idson, T. and Oi, W. (1999). Workers are more productive in large firms. American Economic Review, Papers and Proceedings, 89, pp104-108.

International Monetary Fund (IMF) (2009). World Economic Outlook Update: Contractionary Forces Receding But Weak Recovery Ahead. Available at: http://www.imf.org/external/pubs/ft/weo/2009/update/02/pdf/0709.pdf. Retrieved on 14 February, 2014. 
Katz, J., Aldrick, H., Welbourne, T. and Williams, P. (2000). Guest editors' comments. Special Issue on human resource management and the SMEs: Towards a new synthesis. Entrepreneurship Theory and Practice, 25(1), pp7-10.

Katzenbach, J. and Bromfield, P. (2009). How to cut costs in a recession - with help from employees. Strategy \& Leadership, 37(3), pp.9-16.

Kersley, B., Alpin, C., Forth, J., Bryson, A., Bewley, H., Dix, G. ad Oxenbridge, S. (2006). Inside the Workplace: Findings from the 2004 Workplace Employment Relations Survey. London: Routledge.

Kitching, J. and Marlow, S. (2013). HR practices and small firm growth: Balancing informality and formality. In Saridakis, G. and Cooper, C.L. (eds), How Can HR Drive Growth. Cheltenham: Edward Elgar Publishing Limited. pp26-45.

Kitching, J., Blackburn, R., Smallbone, D. and Dixon, S. (2009b). Business strategies and performance during difficult economic conditions. Paper prepared for the Department of Business Innovation and Skills (BIS). Available at: eprints.kingston.ac.uk/5852/1/Kitching-J-5852.pdf. Retrieved on 12 June, 2014.

Kitching, J., Smallbone, D. and Xheneti, M. (2009a). Have UK small enterprises been victims of the 'credit crunch'? Paper presented at the XXIII RENT conference, Budapest, November 19-20, 2009.

Kitching, J., Smallbone, D., Xheneti, M. and Kasperova, E. (2011). Adapting to a fragile recovery: SME responses to recession and post-recession performance. Paper presented at $34^{\text {th }}$ Institute for Small Business and Entrepreneurship (ISBE) Annual Conference: Sustainable Futures: Enterprising Landscape and Communities. 9-10 November 2011, Sheffield. ISBN: 9781900862233.

Kotey, B and Sheridan, A. (2001). Gender and the practice of HRM in small business. Asia Pacific Journal of Human Resource, 39(3), pp.23-40.

Kotey, B. and Slade, P. (2005). Formal human resource management practices in growing small firms. Journal of Small Business Management, 43(1), pp16-40.

Kroon, B., Van De Voorde, K. and Timmers, J. (2012). High performance work practices in small firms: a resource-poverty and strategic decision-making perspective. Small Business Economics, 41, pp71-91.

Latham, S. (2009). Contrasting strategic responses to economic recession in start-up versus established software firms. Journal of Small Business Management, 47(2): pp180-201.

Leung, A. (2004). Different ties for different needs: Recruitment practices of entrepreneurial firms at different developmental phases. Human Resource Management, 42(4), pp303320.

Liff, S. and Turner, S. (1999). Working in a corner shop: Are employee relations changing in response to competitive advantage. Employee Relations, 21(4): pp419-429.

M Institute (2006). Understanding Medium Enterprises. Available online: http://www.minstitute.org/m_institute/understanding-medium-enterprise.html. Retrieved $26^{\text {th }}$ Oct 2014.

MacMahon, J. and Murphy, E. (1999). Managerial effectiveness in small enterprises: Implications for HRD. Journal of European Industrial Training, 23(1), pp.25-35.

Marlow, S. (2002). Regulating labour management in small firms. Human Resource Management Journal, 12, pp.25-43.

Marlow, S. and Patton, D. (1993). Managing the employment relationship in the smaller firm: possibilities for human resource management. International Small Business Journal, 11, pp.57-64.

Marlow, S., Patton, D. and Ram, M. (2005). Managing Labour in Small firms. London: Routledge.

Mascarehas, B. and Aaker, D. (1989). Strategy over the business cycle. Strategic Management 
Journal, 10(3), pp.199-210.

Matlay, H. (2012). Editorial. Journal of Small Business and Enterprise Development, 19(2).

McCann, A. (2008). Quarterly Survey of Small Business in Britain. Small Enterprises Research Team, Open University Business School. ISSN 1756-5618.

Mintzberg, H., Quinn, J. and Voyer, J. (1995). The Strategy Process. Engle-wood Cliffs, NJ: Prentice Hall.

Mohraman, S.A. and Worley, C.G. (2009). Dealing with rough times: a capabilities development approach to surviving and thriving. Human Resource Management, 48(3), pp.433-445.

Myers, S.C. (1984). The capital structure puzzle. Journal of Finance, 39(3): pp575-592.

Myers, S.C. and Majluf, N.S. (1984). Corporate financing and investment decisions when firms have information that investors do not have. Journal of Financial Economics, 13(2): pp187-221.

Nguyen, T.V. and Bryant, S.E. (2004). A study of the formality of human resource management practices in small and medium-size enterprises in Vietnam. International Small Business Journal, 22, pp595-618.

Organisation for Economic Cooperation and Development (OECD) (2009). Economic Survey of the United Kingdom 2009. Available at: http://www.oecd.org/document/55/0,3343,en_2649_33733_43092599_1_1_1_1,00.ht ml. Retrieved on 18 November, 2013. 7

Peston, R. (2008). The New Capitalism. 15 Feburay 2014. Online at http://www.bbc.co.uk/blogs/thereporters/robertpeston/16_12_09_new_capitalism1.pdf.

Porter, M.E. (1980). Competitive Strategy: Techniques for Analysing Industries and Competitors. New York: The Free Press.

Price, L., Rae, D. and Cini, V. (2013). SME perceptions of and responses to the recession. Journal of Small Business and Enterprise Development, 20(3): pp484-502.

Purcell, J., Kinnie, N., Swart, J., Rayton, B. and Hutchinson, S. (2009). People Management and Performance. London: Routledge.

Rainnie, A. (1989). Industrial Relations in Small Firms: Small Isn't Beautiful. London: Routledge.

Ram, M. (1994). Managing to survive: Working lives in small firms. Blackwell Business.

Ram, M., Edwards, P., Gilman, M. and Arrowsmith, J. (2001). The dynamics of informality: employment relations in small firms and the effects of regulatory change. Work, Employment \& Society, 15(4), pp.845-861.

Rao, M.S. (2009). Is cutting development and training in a recession a good idea? Looking at the IT and ITeS sector in India. Development and Learning in Organisations, 23(5), pp.7-9.

Reid, G. (2007). The Foundations of Small Business Enterprises. London: Routledge.

Revest, V. and Sapio, A. (2010). Financing technology-based small firms in Europe: What do we know? Small Business Economics, 35(1), pp.1-27.

Roche, W.K., Teague, P., Coughlan, A. and Fahy, M.(2011) Human resource in the recession: Managing and representing people at work in Ireland. Executive Summary. Final Report Presented to the Labour Relations Commission.

Rones, P. (1981). Response to recession: reduce hours or jobs? Monthly Labour Review, pp311.

Ryans, C.C. (1989). Managing the Small Business: Insights and Readings. Englewood Cliffs, Prentice Hall.

Sahin, A., Kitao, S., Cororaton, A. and Laiu, S. (2011). Why small businesses were hit harder by the recent recession. Current Issues in Economics and Finance, 17: pp4-10.

Saridakis, G., Sen-Gupta, S., Edwards, P. and Storey, D.J. (2008). The impact of enterprise 
size on employment tribunal incidence and outcomes: Evidence form Britain. British Journal of Industrial Relations, 46, pp469-499.

Saridakis, G., Torres, R.M. and Johnstone, S. (2013). Do human resource practices enhance organisational commitment in SMEs with low employee satisfaction? British Journal of Management, 24, pp.445-458.

Scott, M., Roberts, I., Holroyd, G. and Sawbridge, D. (1989). Management and Industrial Relations in Small Firms. Department of Employment Research Paper. London.

Shama, A. (1993). Marketing strategies during recession: A comparison of small and large firms. Journal of Small Business Management, 31(3), pp.62-72.

Sheehan, M. (2013). Human resource management and performance: Evidence from small and medium-sized firms. International Small Business Journal, pp.1-26. DOI: $10.1177 / 0266242612465454$.

Simpson, D. (2009). The Recession: Causes and Cures. Adam Smith Institute. Available at: http://www.adamsmith.org/images/stories/the-recession.pdf. Retrieved on 15 October, 2013.

Singh, M. and Vohra, M. (2009). Level of formalisation of human resource management in small and medium enterprises in India. Journal of Entrepreneurship, 18(1), pp95-116.

Small Business Service (2001). Small Firms: Big Business. A Review of Small and Medium Sized Enterprises in the UK. London: HMSO.

Smallbone, D., Deakins, D., Battisti, M. and Kitching, J. (2012). Small business responses to a major economic downturn: Empirical perspectives from New Zealand and the Kingdom. International Small Business Journal, 0(0): pp1-24.

Solow, R.M. (1979). Another possible source of wage stickiness. Journal of Macroeconomics, 1, pp.79-82.

Stefaniak, J., Baaki, J. and Blake, A.M. (2012). An examination of the decision-making process used by organizational leaders during the great recession. Performance Improvement Quarterly, 24(4), pp.81-102.

Storey, D. (1994). Understanding the Small Business Sector. London: Routledge.

Storey, D. (2002). Education, training and development policies and practices in mediumsized companies in the UK: Do they really influence firm performance? Omega, 30(4), pp.249-264.

Storey, D. (2004). Exploring the link among small firms, between training and firm performance: a comparison between UK and other OECD countries. International Journal of Human Resource Management, 15(1), pp.112-130.

Storey, D. (2011). Optimism and chance: The elephants in the entrepreneurship room. International Small Business Journal, 29(4): pp303-321.

Storey, D.J. and Skyes, N.S. (1996). Uncertainty, Innovation and management. In Burns, P. and Dewhurst, J. (Eds)., Small Business and Entrepreneurship. London: Palgrave. Pp.7-93.

Storey, D.J., Saridakis, G., Sen-Gupta, S., Edwards, P.K. and Blackburn, R.A. (2010). Linking HR formality with employee job quality: the role of firm and workplace size. Human Resource Management, 49(2). Pp.305-329.

Tansky, J.W. and Heneman, R.L. (2006). Human Resource Strategies for the High-Growth Entrepreneurial Firm. (Eds). Greenwich, CT: Information Age Press.

Timmons, J.A. (1999). New Venture Creation: Entrepreneurship for the $21^{\text {st }}$ Century. New York: Irwin McGraw-Hill.

Tsai, C.J., Sen-Gupta, S. and Edwards, P. (2007). When and why is small beautiful. The experience of work in the small firms. Human Relations, 60(12), pp.1779-1808.

Van Den Berg, R.J., Richardson, H.A. and Eastman, L.J. (1999). The impact of high involvement work processes on organizational effectiveness. Group and Organisation 
Management, 24(3), pp.300-339.

Ward, M. and Rhodes, C. (2014). Small Business and the UK Economy. House of Commons Library, Economic Policy and Statistics Section.

Weale, M. (2009). Commentary: International recession and recovery. National Institute Economic Review, 209: pp.4-7.

Wells, B. (2013). Forward. In Wanrooy, B.V., Bewley, H., Bryson, A., Forth, J., Freeth, S., Stokes, L. and Wood, S. (2013). The 2011 Workplace Employment Relations Study: First Findings. Available at:

Welsh, J.A. and White, J.F. (1981). A small business is not little business. Harvard Business Review, July-August: pp.18-23.

Westhead, P. and Storey, D.J. (1996). Management training and small firm performance: Why is the link so weak? International Small Business Journal, 14(4): pp13-24.

Wickramasinghe, V. and Perera, G. (2012). HRM practices during the global recession (20082010). Evidence for globally distributed software development firms in Sri Lanka. Strategic Outsourcing. An International Journal, 5(3), pp.188-212.

Wright, C.F. (2011). What Role for Trade Union in Future Workplace Relations? Acas Future of Workplace Relations Discussion Paper Series, September 2011. 21 Available at: http://www.acas.org.uk/media/pdf/g/m/What_role_for_trade_unions_in_future_workpl ace_relations.

Wright, C.F. and Boswell, W.R. (2002). Desegregating HRM: A review and synthesis of micro and macro human resource management research. Journal of Management, 28(3), pp.247-276.

Yokoyama, I. (2014). Why do wages become more rigid during a recession than during a boom? IZA Journal of Labour Economics, 3 (6). doi:10.1186/2193-8997-3-6. 
Table 1: The impacts of recession on different sizes of firms (weighted estimates, \%)

\begin{tabular}{|c|c|c|c|c|c|c|}
\hline & Small firms & Medium firms & Large firms & S vs L & M vs L & $S$ vs $M$ \\
\hline Extent & $\%$ & $\%$ & $\%$ & \multicolumn{3}{|c|}{ p-value } \\
\hline No adverse effect & 11.0 & 14.1 & 9.1 & 0.615 & 0.431 & 0.620 \\
\hline Just a little & 20.0 & 14.3 & 12.8 & 0.048 & 0.750 & 0.268 \\
\hline A moderate amount & 21.7 & 30.6 & 37.5 & 0.001 & 0.324 & 0.190 \\
\hline Quite a lot & 24.8 & 28.8 & 26.5 & 0.693 & 0.712 & 0.526 \\
\hline A great deal & 22.5 & 12.2 & 14.0 & 0.049 & 0.668 & 0.021 \\
\hline \multicolumn{7}{|c|}{ Measure 2: This firm is now weaker because of its experience in the recent recession. } \\
\hline & Small firms & Medium firms & Large firms & S vs L & M vs L & S vs $M$ \\
\hline Extent & $\%$ & $\%$ & $\%$ & \multicolumn{3}{|c|}{$\mathrm{p}$-values } \\
\hline Strongly disagree & 20.8 & 25.1 & 22.9 & 0.631 & 0.737 & 0.516 \\
\hline Disagree & 41.2 & 54.1 & 46.2 & 0.351 & 0.275 & 0.078 \\
\hline Neither agree nor disagree & 16.5 & 7.1 & 17.9 & 0.701 & 0.002 & 0.005 \\
\hline Agree & 12.5 & 10.4 & 10.9 & 0.653 & 0.904 & 0.588 \\
\hline Strongly agree & 9.0 & 3.3 & 2.1 & 0.002 & 0.462 & 0.026 \\
\hline
\end{tabular}

Notes: $n=7,168$ employees; 900 firms.

$\mathrm{S}=$ small firms; $\mathrm{M}=$ =medium-sized firm; $\mathrm{L}=$ large firms.

Measure 1 is evaluated on a five-point Likert scale: no adverse effect=1, just a little=2, a moderate amount=3, quite a lot=4 or a great deal=5.

Measure 2 is evaluated on a five-point Likert scale: strongly disagree $=1$, disagree $=2$, neither agree nor disagree $=3$, agree $=4$ or strongly agree $=5$.

We tested whether small, medium and large firms differ statistically and significantly from each other. The results are shown in the last three columns. For measure 1 , statistically significant differences are more likely to be observed when small and large firms groups are compared. For measure 2, statistically significant differences are observed between small and medium sized firms. 
Table 2: Actions taken in response to the recent recession - MQ (weighted estimates, \%)

\begin{tabular}{|c|c|c|c|c|c|c|}
\hline & Small firms & Medium firms & Large firms & S vs L & M vs L & S vs $\mathrm{M}$ \\
\hline Measures $($ yes $=1$ or no $=0$ ) & $\%$ & $\%$ & $\%$ & & p-value & \\
\hline No actions were taken & 26.9 & 21.8 & 21.8 & 0.274 & 0.995 & 0.379 \\
\hline Compulsory redundancies & 20.7 & 31.1 & 28.1 & 0.121 & 0.669 & 0.137 \\
\hline Voluntary redundancies & 4.5 & 11.9 & 22.8 & 0.000 & 0.021 & 0.043 \\
\hline Temporary freeze on recruitment to fill vacancy & 18.5 & 36.8 & 45.6 & 0.000 & 0.222 & 0.007 \\
\hline Postponement of plans for expanding the business & 24.2 & 29.2 & 22.7 & 0.728 & 0.341 & 0.470 \\
\hline Freeze or cut in wages & 43.4 & 44.1 & 31.6 & 0.018 & 0.075 & 0.921 \\
\hline Reduction in non-wage benefits & 6.4 & 5.2 & 8.2 & 0.508 & 0.315 & 0.683 \\
\hline Reduction in basic hours & 13.3 & 8.1 & 10.5 & 0.348 & 0.446 & 0.125 \\
\hline Reduction in paid overtime & 16.3 & 28.6 & 26.6 & 0.016 & 0.769 & 0.062 \\
\hline Employees required to take unpaid leave & 2.3 & 2.6 & 4.3 & 0.206 & 0.411 & 0.880 \\
\hline $\begin{array}{l}\text { Reduction in the use of agency staff or temporary } \\
\text { worker }\end{array}$ & 9.0 & 43.1 & 32.2 & 0.000 & 0.147 & 0.000 \\
\hline Increase in the use of agency staff or temporary worker & 0.7 & 3.0 & 7.3 & 0.003 & 0.121 & 0.193 \\
\hline Reduction in training expenditure & 14.7 & 19.5 & 22.4 & 0.057 & 0.603 & 0.378 \\
\hline Change in the organisation of work & 25.1 & 26.2 & 34.0 & 0.080 & 0.258 & 0.869 \\
\hline
\end{tabular}

$\mathrm{S}=$ small firs; $\mathrm{M}=$ medium firms; $\mathrm{L}=$ large firms.

We tested whether small, medium and large firms differ statistically and significantly from each other. Results are presented in the last three columns. Generally, statistically significant differences are observed when small and large firms groups are compared. 
Table 3: Changes experienced by employees as a result of recession - EQ (weighted estimates, \%)

\begin{tabular}{|c|c|c|c|c|c|c|}
\hline & Small firms & Medium firms & Large firms & S vs L & M vs L & S vs $M$ \\
\hline Measures (yes $=1$ or no $=0$ ) & $\%$ & $\%$ & $\%$ & & p-value & \\
\hline No specified changes experienced & 51.9 & 42.4 & 45.7 & 0.035 & 0.310 & 0.011 \\
\hline My workload increased & 20.1 & 23.3 & 27.7 & 0.001 & 0.030 & 0.177 \\
\hline I was moved to another job & 10.9 & 16.5 & 16.2 & 0.000 & 0.862 & 0.002 \\
\hline My work is re-organised & 2.8 & 4.9 & 5.4 & 0.001 & 0.625 & 0.030 \\
\hline My wages were frozen or cut & 27.3 & 35.0 & 22.1 & 0.061 & 0.000 & 0.035 \\
\hline My non-wage benefits were reduced & 2.8 & 2.8 & 4.7 & 0.033 & 0.042 & 0.963 \\
\hline My contracted hours were reduced & 8.6 & 7.5 & 3.3 & 0.000 & 0.002 & 0.538 \\
\hline Access to paid overtime was restricted & 13.5 & 15.6 & 20.4 & 0.002 & 0.055 & 0.436 \\
\hline I was required to take unpaid leave & 1.7 & 1.8 & 1.9 & 0.814 & 0.885 & 0.938 \\
\hline Access to training was restricted & 5.7 & 8.0 & 9.2 & 0.004 & 0.392 & 0.050 \\
\hline
\end{tabular}

Notes: $n=7,168$ employees; 900 firms.

$\mathrm{S}=$ small firms; $\mathrm{M}=$ medium-sized firms; $\mathrm{L}=$ large firms.

We tested whether small, medium and large firms differ statistically and significantly differ from each other. P-values are shown in the last three columns. Generally, statistically significant differences are observed when small and large firms groups are compared. 
Table 4: The impact of recession on firm: the role of firm size

\begin{tabular}{lc|c}
\hline The impact of recession on firm & $\begin{array}{c}\text { The firm has been adversely } \\
\text { affected by the recession }\end{array}$ & $\begin{array}{c}\text { The firm is weaker now due } \\
\text { to the recession }\end{array}$ \\
\hline Ordered probit regression & coefficient & coefficient \\
\hline Firm size (base category: large firms) & & $0.123^{* * *}$ \\
Small firms (5-49 employees) & 0.028 & 0.039 \\
Medium firms (50-249 employees) & 0.038 & -0.035 \\
& $0.139^{* * *}$ & 0.036 \\
Any form of action (base category: no & 0.035 & \\
action) & & \\
At least one form of actions was taken & & $0.273^{* * *}$ \\
Formalised HRM policies $\quad$ (base & $0.888^{* * *}$ & 0.035 \\
category: low HR formality) & 0.034 & \\
High HRM formality index & & $-0.162^{* * *}$ \\
& -0.023 & 0.044 \\
Controls (individual/firm characteristics) & 0.044 & $y=5$ \\
Log likelihood & & $-9,206.11$ \\
Chi2 (degrees of freedom) & $y e s$ & $1258.34(47)$ \\
obs. & $-9,413.87$ & 7,168 \\
\hline
\end{tabular}

Notes: $n=900$ firms.

Values underneath the coefficients and in italic are standard errors.

HR formality is proxied by $12 \mathrm{HR}$ practices and policies, ranging from $0-1$. To create an overall index, the means are grouped in their nearer discrete values of $0(0-0.49)$ for low HR formality and $1(0.50-1.0)$ for high HR formality.

$* * * \mathrm{p}<0.01$ 
Table 5: Estimation of individual action taken by firms due to recent recession, to be continued

\begin{tabular}{|c|c|c|c|c|c|c|}
\hline Actions & $\begin{array}{l}\text { Compulsory } \\
\text { redundancies }\end{array}$ & $\begin{array}{l}\text { Voluntary } \\
\text { redundancies }\end{array}$ & $\begin{array}{l}\text { Temporary } \\
\text { freeze on } \\
\text { recruitment to } \\
\text { fill vacancy }\end{array}$ & $\begin{array}{l}\text { Postponement of } \\
\text { plans for expanding } \\
\text { the business }\end{array}$ & $\begin{array}{l}\text { Freeze or cut in } \\
\text { wages }\end{array}$ & $\begin{array}{c}\text { Reduction in } \\
\text { non-wage } \\
\text { benefits }\end{array}$ \\
\hline Probit & coefficient & coefficient & coefficient & coefficient & coefficient & coefficient \\
\hline \multicolumn{7}{|l|}{ Firm size (base category: large firms) } \\
\hline \multirow[t]{2}{*}{ Small firms (5-49 employees) } & $-0.234 * * *$ & $-0.658 * * *$ & $-0.650 * * *$ & 0.007 & $0.205^{* * *}$ & -0.077 \\
\hline & 0.057 & 0.068 & 0.051 & 0.051 & 0.046 & 0.076 \\
\hline \multirow[t]{2}{*}{ Medium firms (50-249 employees) } & $0.086^{*}$ & $-0.177 * * *$ & $-0.151 * * *$ & $0.091 *$ & $0.242 * * *$ & $-0.131 *$ \\
\hline & 0.050 & 0.054 & 0.044 & 0.047 & 0.043 & 0.073 \\
\hline \multicolumn{7}{|c|}{ Formalised HRM policies (base category : low HRM formality) } \\
\hline \multirow[t]{2}{*}{ High HRM formality index } & $0.486 * * *$ & $0.643 * * *$ & $0.511^{* * *}$ & $0.197 * * *$ & $0.161^{* * *}$ & -0.056 \\
\hline & 0.068 & 0.105 & 0.062 & 0.059 & 0.054 & 0.088 \\
\hline Controls & yes & yes & yes & yes & yes & yes \\
\hline Log likelihood & $-3,168.94$ & $-2,625.20$ & $-4,068.05$ & $-3,609.80$ & $-4,482.47$ & $-1,578.86$ \\
\hline Chi2 (degree of freedom) & $1,549.05(46)$ & $1,327.01(46)$ & $1,362.25(47)$ & $752.96(47)$ & 752.92(47) & 406.96(46) \\
\hline obs. & $6,651^{1}$ & $6,651^{1}$ & 7,168 & 7,168 & 7,168 & $6,988^{2}$ \\
\hline
\end{tabular}


Table 5: continued

\begin{tabular}{|c|c|c|c|c|c|c|c|}
\hline Actions & $\begin{array}{l}\text { Reduction in } \\
\text { basic hours }\end{array}$ & $\begin{array}{l}\text { Reduction in } \\
\text { paid overtime }\end{array}$ & $\begin{array}{l}\text { Employees } \\
\text { required to } \\
\text { take unpaid } \\
\quad \text { leave }\end{array}$ & $\begin{array}{l}\text { Reduction in } \\
\text { the use of } \\
\text { agency staff or } \\
\text { temporary } \\
\text { worker }\end{array}$ & $\begin{array}{l}\text { Increase in } \\
\text { the use of } \\
\text { agency staff } \\
\text { or } \\
\text { temporary } \\
\text { worker }\end{array}$ & $\begin{array}{l}\text { Reduction } \\
\text { in training } \\
\text { expenditure }\end{array}$ & $\begin{array}{l}\text { Change in the } \\
\text { organisation } \\
\text { of work }\end{array}$ \\
\hline Probit & coefficient & coefficient & coefficient & coefficient & coefficient & coefficient & coefficient \\
\hline \multicolumn{8}{|l|}{ Firm size (base category: large firms) } \\
\hline \multirow[t]{2}{*}{ Small firms (5-49 employees) } & $-0.153^{* *}$ & $-0.149 * * *$ & $-0.678 * * *$ & $-0.839 * * *$ & $-0.579 * * *$ & $-0.316^{* * *}$ & $-0.103^{* *}$ \\
\hline & 0.066 & 0.055 & 0.132 & 0.057 & 0.144 & 0.053 & 0.050 \\
\hline \multirow[t]{2}{*}{ Medium firms (50-249 employees) } & $-0.192 * * *$ & - & $-0.332 * * *$ & -0.057 & -0.010 & -0.010 & $-0.093 * *$ \\
\hline & 0.064 & & 0.116 & 0.045 & 0.094 & 0.047 & 0.046 \\
\hline \multicolumn{8}{|c|}{ Formalised HRM policies (base category: low HRM formality) } \\
\hline \multirow[t]{2}{*}{ High HRM formality index } & 0.039 & $0.441^{* * *}$ & $-0.440 * * *$ & $0.467 * * *$ & $-0.512 * * *$ & $0.176^{* * *}$ & $0.219 * * *$ \\
\hline & 0.071 & 0.067 & 0.133 & 0.073 & 0.140 & 0.063 & 0.060 \\
\hline Controls & yes & yes & yes & yes & yes & yes & yes \\
\hline Log likelihood & $-2,057.37$ & $-3,485.87$ & -696.89 & $-3,360.02$ & -872.10 & $-3,471.32$ & $-3,889.69$ \\
\hline Chi2 (degree of freedom) & $951.08(46)$ & $1100.87(47)$ & 233.03(42) & $1,151.97(47)$ & 334.63(43) & $693.86(47)$ & $1,076.63(47)$ \\
\hline obs. & $6,988^{2}$ & 7,168 & $3,541^{3}$ & 7,168 & $5,058^{4}$ & 7,168 & 7,168 \\
\hline
\end{tabular}

Notes: All estimations control for employee and firm characteristics. Full tables are available on request.

Values underneath the coefficients and in italic are standard errors.

${ }^{1}$ All the firms that were not adversely affected by the recession (517obs.) did not take actions: 'make compulsory' or 'voluntary redundancy' actions.

${ }^{2}$ All the firms in the Utility industry (180 obs.) did not take actions: 'reduce non-wage benefits' or 'basic hours'.

${ }^{3}$ All the firms that were not adversely affected by the recession (517obs); and in the Information and Communication (232 obs.), Financial and Real Estate industry (469

obs.) and Health and Education industries 11 (2,025 obs.); and competed in growing market (384obs.) did not take action: 'Employees required to take unpaid leave'.

${ }^{4}$ All the firms in the Information and Communication (240ob.s), Admin and support service (288obs.) and Arts, Entertainment and Recreation industries (390 obs.); and competed in mature market (1,192 obs.) did not take action: 'increase in the use of agency staff or temporary worker'.

${ }^{* * *} \mathrm{p}<0.01 ; * * \mathrm{p}<0.05 ;{ }^{*} \mathrm{p}<0.10$. 
Table 6: Estimation of individual change experienced by employees due to the recession

\begin{tabular}{|c|c|c|c|c|c|c|c|c|c|}
\hline Changes & $\begin{array}{c}\text { My } \\
\text { workload } \\
\text { increased }\end{array}$ & $\begin{array}{c}\text { I was } \\
\text { moved to } \\
\text { another job }\end{array}$ & $\begin{array}{c}\text { My work is } \\
\text { re- } \\
\text { organised }\end{array}$ & $\begin{array}{l}\text { My wages } \\
\text { were } \\
\text { frozen or } \\
\text { cut }\end{array}$ & $\begin{array}{l}\text { My non- } \\
\text { wage } \\
\text { benefits } \\
\text { were } \\
\text { reduced } \\
\end{array}$ & $\begin{array}{c}\text { My } \\
\text { contracted } \\
\text { hours were } \\
\text { reduced }\end{array}$ & $\begin{array}{l}\text { Access to } \\
\text { paid } \\
\text { overtime } \\
\text { was } \\
\text { restricted }\end{array}$ & $\begin{array}{l}\text { I was } \\
\text { required to } \\
\text { take unpaid } \\
\text { leave }\end{array}$ & $\begin{array}{l}\text { Access to } \\
\text { training } \\
\text { was } \\
\text { restricted }\end{array}$ \\
\hline Probit & coefficient & coefficient & coefficient & coefficient & coefficient & coefficient & coefficient & coefficient & coefficient \\
\hline \multicolumn{10}{|l|}{$\begin{array}{l}\text { Firm size (base category = large } \\
\text { firms) }\end{array}$} \\
\hline \multirow[t]{2}{*}{ Small firms (5-49 employees) } & -0.055 & -0.070 & -0.084 & $0.197 * * *$ & $-0.198 * *$ & $0.276 * * *$ & $-0.113^{*}$ & $-0.315 * *$ & -0.090 \\
\hline & 0.051 & 0.057 & 0.085 & 0.050 & 0.087 & 0.075 & 0.059 & 0.124 & 0.068 \\
\hline \multirow[t]{2}{*}{ Medium firms (50-249 employees) } & 0.009 & 0.024 & -0.039 & $0.344 * * *$ & -0.094 & $0.264^{* * *}$ & -0.047 & -0.080 & 0.074 \\
\hline & 0.046 & 0.051 & 0.075 & 0.045 & 0.077 & 0.071 & 0.054 & 0.110 & 0.060 \\
\hline \multicolumn{10}{|c|}{ Formalised HRM policies (base category = low HRM formality) } \\
\hline \multirow[t]{2}{*}{ High HRM formality index } & $0.216^{* * *}$ & $0.163^{* *}$ & 0.040 & $0.205 * * *$ & 0.052 & 0.091 & $0.210 * * *$ & $-0.278 * *$ & 0.110 \\
\hline & 0.060 & 0.068 & 0.104 & 0.058 & 0.105 & 0.079 & 0.069 & 0.124 & 0.085 \\
\hline Controls & yes & yes & yes & yes & yes & yes & yes & yes & yes \\
\hline Log likelihood & $-3,765.86$ & $-2,964.37$ & $-1,232.50$ & $-3,877.28$ & $-1,192.86$ & $-1,384.03$ & $-2,865.98$ & -594.68 & $-1,925.39$ \\
\hline Chi2 (degree of freedom) & 445.33(47) & 270.95(47) & 119.59(47) & 836.85(47) & 198.86(47) & $351.76(47)$ & $676.62(47)$ & $141.27(46)$ & $335.99(47)$ \\
\hline obs. & 7,168 & 7,168 & 7,168 & 7,168 & 7,168 & 7,168 & 7,168 & $6,928^{1}$ & 7,168 \\
\hline
\end{tabular}

Notes: Values underneath the coefficients and in italic are standard errors.

${ }^{1}$ None of the employees in the Information and Communication Industry (240 obs.) experiences 'I was required to take unpaid leave'.

We checked the robustness of the estimation results by using the logistic regression, and the results are same (results are available upon request).

${ }^{* * *} \mathrm{p}<0.01 ;{ }^{* *} \mathrm{p}<0.05 ;{ }^{*} \mathrm{p}<0.10$. 


\section{Appendix}

Table A1: Statistical summary of employee and firm characteristics (weighted estimates ${ }^{\mathrm{a}}$, \%)

\begin{tabular}{|c|c|c|c|c|}
\hline & $\begin{array}{l}\text { Small } \\
\text { Firms } \\
(27.08)\end{array}$ & $\begin{array}{c}\text { Medium } \\
\text { Firms } \\
\text { (16.73) }\end{array}$ & $\begin{array}{c}\text { Large } \\
\text { Firms } \\
\text { (56.19) }\end{array}$ & Overall \\
\hline \multicolumn{5}{|l|}{ Employee characteristics } \\
\hline Trade union member (base cat.: no member) & 5.4 & 12.0 & 27.8 & 19.1 \\
\hline \multicolumn{5}{|l|}{ Job tenure (base cat.: less than 1yr) } \\
\hline Less than $1 \mathrm{yr}$ & 7.5 & 5.4 & 6.4 & 6.5 \\
\hline 1 to less than $2 y r s$ & 10.7 & 11.1 & 9.4 & 10.0 \\
\hline 2 to less than $5 y r s$ & 29.3 & 34.2 & 27.5 & 29.1 \\
\hline 5 to less than $10 y r s$ & 28.3 & 27.3 & 26.9 & 27.4 \\
\hline $10 \mathrm{yrs}$ or more & 24.1 & 21.9 & 29.8 & 27.0 \\
\hline Permanent (base cat.: temporary or fixed term) & 94.7 & 95.7 & 92.0 & 94.5 \\
\hline Female (base cat.: male) & 52.1 & 43.2 & 47.5 & 48.0 \\
\hline \multicolumn{5}{|l|}{ Age (base cat.: 16-21yrs) } \\
\hline 16-21yrs & 6.2 & 4.3 & 5.7 & 5.6 \\
\hline 22-29yrs & 18.5 & 14.1 & 17.1 & 17.0 \\
\hline 30-39yrs & 21.3 & 25.6 & 21.7 & 22.3 \\
\hline 40-49yrs & 26.0 & 25.1 & 24.7 & 25.2 \\
\hline 50-59yrs & 18.7 & 22.8 & 22.4 & 21.5 \\
\hline $60-65+y r s$ & 9.2 & 8.1 & 8.4 & 8.5 \\
\hline Long-term illness (base cat.: no long-term illness) & 7.0 & 7.8 & 10.8 & 9.2 \\
\hline $\begin{array}{l}\text { Academic qualification (i.e. GCSE or above qualification) (base } \\
\text { cat.: no university degree) }\end{array}$ & 94.7 & 93.1 & 93.3 & 93.6 \\
\hline $\begin{array}{l}\text { Supervisory responsibilities (base cat.: no supervisory } \\
\text { responsibilities) }\end{array}$ & 39.5 & 37.4 & 34.5 & 36.4 \\
\hline \multicolumn{5}{|l|}{ Wage (base cat.: £60-100 per week) } \\
\hline$£ 60-100$ per week & 9.1 & 5.7 & 6.7 & 7.2 \\
\hline$£ 101-220$ per week & 17.4 & 10.1 & 16.2 & 15.5 \\
\hline$£ 221-310$ per week & 18.2 & 15.9 & 17.2 & 17.3 \\
\hline$£ 311-430$ per week & 18.9 & 23.8 & 19.6 & 20.1 \\
\hline$£ 431-520$ per week & 12.2 & 14.6 & 9.8 & 11.3 \\
\hline$£ 521-650$ per week & 9.3 & 12.2 & 11.4 & 11.0 \\
\hline$£ 651-820$ per week & 6.3 & 7.2 & 9.1 & 8.1 \\
\hline$£ 821-1,050$ per week & 3.7 & 3.3. & 5.0 & 4.3 \\
\hline$£ 1,050+$ per week & 4.9 & 7.1 & 5.0 & 5.3 \\
\hline British (base cat.: non-British) & 89.1 & 85.2 & 84.0 & 85.6 \\
\hline \multicolumn{5}{|l|}{ Firm characteristics } \\
\hline $\begin{array}{l}\text { Organisation is weaker due to the recession (base cat.: strongly } \\
\text { disagree/disagree/neutral) }\end{array}$ & 21.5 & 13.7 & 13.0 & 15.4 \\
\hline $\begin{array}{l}\text { Organisation is adversely affected by the recession (base cat.: } \\
\text { no adverse effect) }\end{array}$ & 89.0 & 85.9 & 90.9 & 89.5 \\
\hline \multicolumn{5}{|l|}{ Industry (base cat.: manufacturing) } \\
\hline Manufacturing & 10.9 & 18.2 & 13.1 & 13.3 \\
\hline Utility & 0.2 & 0.2 & 1.0 & 0.6 \\
\hline
\end{tabular}




\begin{tabular}{|c|c|c|c|c|}
\hline Construction & 8.8 & 4.7 & 1.5 & 4.0 \\
\hline Wholesale and retail & 17.7 & 13.1 & 23.9 & 20.4 \\
\hline Transportation and storage & 1.0 & 3.4 & 9.5 & 6.1 \\
\hline Accommodation and food service & 8.3 & 6.6 & 5.0 & 6.2 \\
\hline Information and communication & 4.8 & 10.2 & 4.1 & 5.3 \\
\hline Financial and real estate activities & 5.9 & 11.8 & 11.6 & 10.1 \\
\hline Professional, scientific and technical & 17.0 & 6.4 & 5.5 & 8.8 \\
\hline Admin and support service & 3.4 & 3.0 & 4.7 & 4.0 \\
\hline Health and Education & 20.5 & 19.8 & 18.2 & 19.1 \\
\hline Arts, entertainment and recreation & 1.8 & 2.6 & 1.9 & 2.0 \\
\hline $\begin{array}{l}\text { Recognised trade union or association (base cat.: no trade union } \\
\text { resence) }\end{array}$ & 10.5 & 32.6 & 61.8 & 43.0 \\
\hline \multicolumn{5}{|l|}{ Degree of competition (base cat.: high degree) } \\
\hline High & 66.9 & 82.1 & 79.1 & 76.3 \\
\hline Neutral & 22.2 & 7.0 & 11.8 & 13.8 \\
\hline Low & 10.9 & 11.0 & 9.1 & 9.9 \\
\hline \multicolumn{5}{|l|}{ Current state of market (base cat.: turbulent) } \\
\hline Turbulent & 32.8 & 37.4 & 33.2 & 33.8 \\
\hline Declining & 16.5 & 18.6 & 13.9 & 15.4 \\
\hline Mature & 20.5 & 14.5 & 17.5 & 17.8 \\
\hline Growing & 30.2 & 28.5 & 35.5 & 33.0 \\
\hline Age $(\ln )^{a}$ & 2.794 & 2.831 & 3.113 & 2.979 \\
\hline Formal HR policies ${ }^{\mathrm{a}}$ & 0.436 & 0.628 & 0.775 & 0.659 \\
\hline
\end{tabular}

Notes: $n=7,168$ employees; 900 firms.

${ }^{a}$ Weighted means are reported for continuous variables only. 